EMILIANO RODRIGO DE BARROS ARRUDA

\title{
AVALIAÇÃO DE UM VITROCERÂMICO ELABORADO A PARTIR DO GENÉRICO DO BIOVIDRO 45S5 EM PERFURAÇÕES DE TÍBIAS DE RATOS, E SEU COMPORTAMENTO SOB INFLUÊNCIA DA RADIAÇÃO LASER DE BAIXA INTENSIDADE.
}

Dissertação de mestrado apresentado ao Programa de Pós-Graduação Interunidades em Bioengenharia (Escola de Engenharia de São Carlos, Instituto de Química de São Carlos e Faculdade de Medicina de Ribeirão Preto) da Universidade de São Paulo como parte do requisito para obtenção do título de Mestre em Bioengenharia.

Área de Concentração: Bioengenharia

Orientador: Prof. Dr. João M. Domingos de Almeida Rollo

São Carlos-SP

2008 
Este trabalho é dedicado aos meus filhos Enzo e Elizabeth, razão da minha vida e motivo de alegria e esperança. 


\title{
AGRADECIMENTOS
}

\begin{abstract}
À Deus.
Senhor obrigado pela vida que tu me deste e pela tua constante presença em minha caminhada.
\end{abstract}

À minha mãe Regina que muitas vezes abdicou de seus sonhos e vontades para que os meus se tornassem possíveis, tenho um orgulho muito grande em ser seu filho. Esta conquista não é somente minha, mas também sua. Muito obrigado mãe.

Ao meu pai Edson In memorian, que apesar de não estar presente fisicamente, sempre foi motivo de orgulho e inspiração para mim.

À minha esposa Carol pela sua dedicação e paciência nos momentos em que não pude estar presente, pela sua ajuda e compreensão, esta vitória é nossa. Eu te amo.

Aos meus irmãos Estevan e Eder que sempre compartilharam comigo as alegrias e dificuldades. Obrigado.

Aos meus avós que com muito sacrifício ajudaram a nos criar, espero honrar sua generosidade para comigo. Amo vocês.

Aos colegas de laboratório de eletrotermofototerapia da UFSCar. Obrigado pelos conhecimentos compartilhados e a ajuda a mim dispensada. 
Ao Professor Dr. Paulo Sergio Pizani pelo auxílio com a análise de micro Raman realizada no Departamento de Física da Universidade Federal de São Carlos.

Ao professor José Heraldo Gallo pelo auxílio com a Difração de Raios-X realizada no laboratório de cristalografia do IFSC-USP.

Aos colegas do laboratório de histologia da UNESP de Araraquara pela amizade, e colaboração no processamento das lâminas histológicas.

À Capes pela concessão da bolsa durante o período de realização deste trabalho.

\section{AGRADECIMENTOS ESPECIAIS}

Ao prof. Dr. João Manuel Domingos de Almeida Rollo, orientador deste trabalho, sempre presente na arte do ensino e pronto a ajudar na resolução dos problemas. Agradeço pelas oportunidades e principalmente pela confiança depositada em mim durante estes meses. Espero não decepcioná-lo nunca.

Ao prof. Dr. Nivaldo Antonio Parizotto, co-orientador deste trabalho, meu mentor científico, grande cientista, expoente no ensino e na pesquisa. Sua sabedoria consegue com poucas palavras esclarecer as mais difíceis dúvidas. O senhor é exemplo de vida e dedicação profissional. Suas atitudes formaram um discípulo e acima de tudo um admirador. 


\section{RESUMO}

ARRUDA, E. R. B. Avaliação de um vitrocerâmico elaborado a partir do genérico do biovidro $45 \mathrm{~S} 5 \mathrm{em}$ perfurações de tíbias de ratos, e seu comportamento sob influência da radiação laser de baixa intensidade. 2008. 77f. Dissertação (mestrado) - Programa de PósGraduação Interunidades em Bioengenharia - Escola de Engenharia de São Carlos, Faculdade de Medicina de Ribeirão Preto, Instituto de Química de São Carlos, Universidade de São Paulo, São Carlos, 2008.

O presente trabalho avaliou os efeitos provocados pela laserterapia de baixa intensidade (LTBI) no $\lambda 780 \mathrm{~nm}, 30 \mathrm{~mW}$ de potência e tempo de exposição de 150 segundos, resultando em uma fluência de $112,5 \mathrm{~J} / \mathrm{cm}^{2}$ e energia total de $4,5 \mathrm{~J}$, sobre o comportamento osteocondutor da vitrocerâmica elaborada a partir do genérico do biovidro de composição: 45\% $\mathrm{SiO}_{2}, 24,5 \%$ $\mathrm{Na}_{2} \mathrm{O}, 24,5 \% \mathrm{CaO}$ e $6 \% \mathrm{P}_{2} \mathrm{O}_{5}$ em perfurações ósseas em tíbias de ratos. O biovidro foi recozido em cuba de inox acima de sua temperatura de transição vítrea, a $620^{\circ} \mathrm{C}$ por 30 minutos e mantido a $790^{\circ} \mathrm{C}$ por 60 minutos, em seguida foi realizada a espectroscopia Raman para verificar a cristalinidade. Foram realizadas perfurações abaixo da tuberosidade da tíbia direita de 64 machos de ratos da raça Wistar (Rattus norvegicus albinus) na idade adulta. Os mesmos foram divididos aleatoriamente em 4 grupos sendo eles: um controle e três submetidos à procedimento experimental de implante e/ou irradiação laser de baixa intensidade. Em todos os grupos foram utilizados 16 indivíduos. Posteriormente, os animais de cada grupo foram subdivididos em dois subgrupos cada, de acordo com o tempo de vida antes da eutanásia, que ocorreu com 7 e 13 dias P.O. A análise das características das fibras colágenas para determinar a neoformação tecidual, bem como seu estado de maturação, foi realizada através de corpos de prova em forma de lâminas coradas com HE observadas à microscopia de luz comum para verificar a presença de células no foco de lesão, lâminas coradas com Picro Sirius sob luz polarizada a fim de verificar o estado organizacional e microscopia eletrônica de varredura, utilizando métodos técnico-experimentais para avaliar a interação do biomaterial com o tecido ósseo. Os valores de birrefringência demonstraram uma melhor organização tecidual dos grupos irradiados com ou sem o implante de vitrocerâmico $(\mathrm{p}<0,05)$, os grupos com vitrocerâmico apresentaram o tecido mais difuso, até mesmo nas regiões mais centrais da lesão aos 13 dias. O vitrocerâmico estimulou a proliferação osteoblástica $(\mathrm{p}<0,05)$, assim como a radiação laser $(\mathrm{p}<0,01)$. Pode - se concluir que o vitrocerâmico utilizado apresenta capacidade osteocondutora e que a radiação laser acelerou o processo de reparo na presença ou não do vitrocerâmico.

Palavras chave: laser de baixa intensidade, vitrocerâmica, reparo ósseo, ratos. 


\begin{abstract}
ARRUDA, E. R. B. Evaluation of a Glass ceramic produced from the generic of bioglass $45 S 5$ in drilling of tibias of rats, and their behavior under the influence of low-intensity laser radiation. 2008. 77f. MSc. Dissertation - Programa de Pós-Graduação Interunidades em Bioengenharia - Escola de Engenharia de São Carlos, Faculdade de Medicina de Ribeirão Preto, Instituto de Química de São Carlos, Universidade de São Paulo, São Carlos, 2008.

The present study evaluated the effects caused by the Low Level Laser Therapy (LLLT) at $\lambda$ $780 \mathrm{~nm}$, power of $30 \mathrm{~mW}$ and dose of $112.5 \mathrm{j} / \mathrm{cm}^{2}$ and total energy of $4,5 \mathrm{~J}$ on the behavior osteoconductor of the glass-ceramic drafted from generic of bioglass of composition: 45\% $\mathrm{SiO} 2,24.5 \% \mathrm{Na} 2 \mathrm{O}, 24.5 \% \mathrm{CaO}$ and $6 \% \mathrm{P} 2 \mathrm{O} 5$ in drillings in tibia bone of rats. The bioglass was anneal in cuba of stainless above its glass transition temperature, to $620^{\circ} \mathrm{C}$ for 30 minutes and maintained at $790^{\circ} \mathrm{C}$ for 60 minutes, then was held to Raman spectroscopy to verify the crystallinity. Drillings were made below the tuberosity of the right tibia of 64 males of the race Wistar rats (Rattus Norvegicus Albinus) in adult age. They were randomly divided into 4 groups which are: a control and three underwent experimental procedure to implant and/or of low intensity laser irradiation. In all groups were used 16 individuals. Later, the animals in each group were further divided into two subgroups each, according to the time of life before euthanasia, which occurs with 7 and 13 days postoperative. The analysis of the characteristics of collagen fibers was conducted through: Slides stained with HE seen the light microscopy, to quantify the presence of cells in the focus of injury, slides stained with Picro Sirius Red under polarized light to verify the organizational state, microscope electronic scanning, using technical experimental methods to evaluate the interaction of biomaterial with the bone tissue. The values of birefringence showed better tissue organization of groups irradiated with or without the implant of glass-ceramic ( $p$ $<0.05$ ), the groups with glass-ceramic showed collagen fibers more diffuse, even in the most central of injury to 13 days. The glass-ceramic stimulated the osteoblast proliferation ( $p$ $<0.05)$ as well as laser radiation $(\mathrm{p}<0.01)$. thus it is possible to conclude that the glass-cerâmic has osteoconductive capacity and that laser radiation accelerated the process of repairing in the presence or not of glass-ceramic.
\end{abstract}

Key words: Low-intensity Laser, glass-ceramic, bone repair, rats 


\section{LISTA DE SIMBOLOS}

${ }^{\circ} \mathrm{C}$

$\mathrm{Ca}^{+2}$

J

$\mathrm{SiO}_{2}$

$\mathrm{Na}_{2} \mathrm{O}$

$\mathrm{CaO}$

$\mathbf{P}_{2} \mathbf{O}_{5}$

P.O.

HE

$\mathrm{Ca}_{10}\left(\mathrm{PO}_{4}\right)_{6}(\mathrm{OH})_{2}$

nm

$\mu \mathrm{m}$

LTBI

$\mathrm{He}-\mathrm{Ne}$

As-Ga-Al

Ga-As

mW

$\mathbf{c m}^{2}$

$\lambda$

$\mathrm{Hz}$

GC

GL

GV

GVL
Graus Celsius

Íons Cálcio

Joules

Sílica

Óxido de Sódio

Óxido de Cálcio

Fosfato

Pós Operatório

Hematoxilina e Eosina

Hidroxiapatita

Nanômetro

Micrômetro

Laser Terapia de Baixa Intensidade

Hélio neônio

Arsenieto de Gálio e alumínio

Arsenieto de Gálio

Miliwatts

Centímetros Quadrados

Comprimento de onda

Hertz

Grupo controle

Grupo submetido à radiação laser

Grupo submetido à aplicação do vitrocerâmico

Grupo submetido à radiação laser pós implante do vitrocerâmico 


\section{LISTA DE TABELAS}

TABELA 1. Médias em "Pixels" da intensidade do brilho de birrefringência aos 7 dias.......46

TABELA 2. Valores de p para diferença entre as médias dos grupos aos 7 dias. .46

TABELA 3. Médias em "Pixels" da intensidade do brilho de birrefringência aos 13 dias.....49

TABELA 4. Valores de p para diferença entre as médias dos grupos aos 13 dias.

TABELA 5. Médias do número de osteoblastos por grupo e seus respectivos desvios aos 7 dias.

TABELA 6. Valores de p para diferença entre as médias do número de osteoblastos entre os grupos aos 7 dias. .53

TABELA 7. Médias do número de osteoblastos por grupo e seus respectivos desvios aos 13 dias.

TABELA 8. Valores de p para diferença entre as médias do número de osteoblastos entre os grupos aos 13 dias. 


\section{LISTA DE FIGURAS}

FIGURA 1. Osso compacto e trabecular (esponjoso).....................................................18

FIGURA 2. Análise térmica diferencial do biovidro de composição: $45 \% \mathrm{SiO}_{2}, 24,5 \% \mathrm{Na}_{2} \mathrm{O}$, $24,5 \% \mathrm{CaO}$ e $6 \% \mathrm{P}_{2} \mathrm{O}_{5}$ evidenciando a temperatura de transição vítrea próximo de $790{ }^{\circ} \mathrm{C} . .31$

FIGURA 3. Espectroscopia Raman comparando as amostras antes e após o tratamento térmico, a cristalinidade é evidente e pode ser observada pela formação de picos de cristalinidade.

FIGURA 4. A DRX evidencia picos de cristalinidade na amostra da vitrocerâmica (A), já a amostra vítrea (B) não apresenta picos de cristalinidade. Destacando a eficiência do

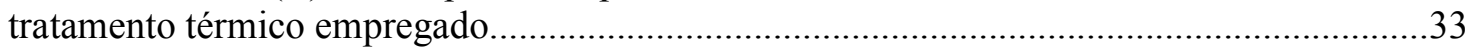

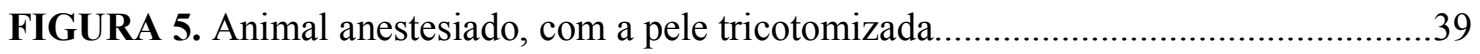

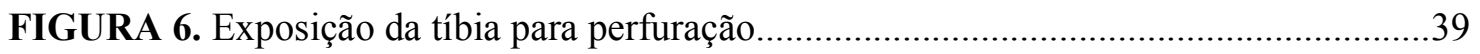

FIGURA 7. Perfuração sendo realizada com a broca, esta era irrigada com soro fisiológico para evitar danos por queimadura.....

FIGURA 8. Defeito ósseo de $2 \mathrm{~mm}$ de diâmetro realizado na tíbia. .40

FIGURA 9. Aplicação do vitrocerâmico com auxílio de um portaamálgama. 40

FIGURA 10. Sutura externa (pele) higienizada com álcool iodado .40

FIGURA 11. Emissor laser de baixa intensidade utilizado no experimento. .41

FIGURA 12. Exemplares de lâminas de animais sacrificados no $7^{\circ}$ dia coradas com Picro Sirius sob luz polarizada (aumento original de 100X), a intensidade do brilho de birrefringência é proporcional à organização das fibras colágenas. $\mathrm{O}$ grupo controle apresenta pouco brilho em comparação com o grupo irradiado (A); o grupo apenas irradiado apresenta brilho moderado (B); o grupo com biomaterial tem pouco de brilho de birrefringência quando comparado com os demais grupos $(\mathrm{C})$; já o grupo com associação de biomateriais com a LTBI apresenta um brilho superior quando comparado com o grupo que apenas recebeu o vitrocerâmico brilho (D). 45

FIGURA 13. . Diferença entre as médias do brilho de birrefringência apresentado pelos grupos, o brilho foi quantificado em "pixels" pelo software imageJ. Os grupos com vitrocerâmico apresentam um atraso na formação de tecido anisotrópico (GV e GVL), em comparação com o controle (GC), esta diferença diminui sob a influencia da radiação laser (GVL), e o grupo apenas irradiado (GL) apresenta maior formação de tecido anisotrópico, sugerindo uma fotoestimulacao do reparo ósseo. 
FIGURA 14. Exemplares de lâminas de animais sacrificados no $13^{\circ}$ dia, coradas com Picro Sirius sob luz polarizada (aumento original de 100X) no controle o brilho é moderado e as fibras localizam-se às margens da lesão (A); no grupo irradiado com laser há um brilho mais intenso e difuso pelo sítio de lesão (B), no grupo com vitrocerâmica as fibras ficam em torno das partículas e apresentam moderado brilho(C) e finalmente no grupo com vitrocerâmica irradiado percebe-se um incremento no brilho e na espessura das fibras colágenas (D) (a seta branca indica a localização das partículas do vitrocerâmico) .48

FIGURA 15. Diferença entre as medias dos grupos, o brilho foi quantificado em "pixels" utilizando o software imageJ. O GV apresenta anisotropia um pouco inferior ao controle (GC), os grupos irradiados apresentam grande incremento na anisotropia (GVL e GL), sendo o GL o grupo com maior quantidade de tecido anisotrópico. .50

FIGURA 16. Exemplares de lâminas coradas com H.E. de animais sacrificados no $7^{\circ}$ dia (100X). A seta branca indica o limite da lesão; a azul, osso secundário; a verde, osso primário; e a preta, partículas de biomaterial. No grupo controle há formação de tecido ósseo primário (osteóide) (A); no grupo irradiado pode-se ver a formação de osso secundário (lamelar) (B); no grupo com biomaterial percebe-se o tecido primário ao redor das partículas de vitrocerâmica (C); já os animais que receberam a aplicação do biomaterial associado à LTBI há uma maior concentração de células osteoblásticas em torno do material com intensa deposição de osso primário. .51

FIGURA 17. Exemplares de lâminas coradas com H.E. de animais sacrificados aos 7 dias (500X). A seta preta indica partículas do biomaterial, a azul tecido secundário e a verde tecido primário. $\mathrm{O}$ grupo controle apresenta grande número de osteoblastos dando origem à tecido osteóide (A); o grupo irradiado apresenta formação de lamelas ósseas (tecido secundário) e vários vasos sanguíneos; o grupo com vitrocerâmica apresenta osteoblastos dando origem a tecido ósseo primário em torno do biomaterial (C); o grupo com vitrocerâmica irradiado apresenta osteoblastos invadindo o biomaterial (D). 52

FIGURA 18. Diferença entre as medias de osteoblastos nos grupos, o GC apresenta a menor contagem de osteoblastos, o GV apresenta um sensível aumento em relação ao GC sugerindo um estimulo positivo na atividade osteoblástica pelo vitrocerâmico, o GL apresenta um aumento consistente sugerindo uma estimulação pela radiação laser, e finalmente o GVL apresentou a maior media, possivelmente pela soma dos estímulos. .53

FIGURA 19. Lâminas dos animais sacrificados com 13 dias, coradas com H.E. (100X). A seta branca indica o limite da lesão; a azul, tecido secundário; a verde, tecido primário; e a preta, partículas de biomaterial. O grupo contole já apresenta abundante tecido ósseo secundário envolvendo tecido primário (A); o grupo irradiado apresenta uma maior quantidade de tecido secundário se comparado ao controle (B); o grupo com biomaterial apresenta a formação de tecido primário em torno do tecido osteóide que circunda o biomaterial (C); o grupo com associação de biomaterial com LTBI apresenta o melhor grau de maturação do tecido com pequena quantidade de tecido secundário e poucas partículas de biomaterial .54

FIGURA 20. Lâminas coradas com H.E. dos animais sacrificados aos 13 dias (aumento original 500X). A seta preta indica partículas do biomaterial; a azul, tecido ósseo secundário; e a verde, tecido primário. O grupo controle apresenta formação óssea secundária ao redor do 
limite de lesão e parte do centro da mesma (A); o grupo irradiado apresenta-se no final do reparo, onde o tecido primário esta quase todo substituído por secundário $(\mathrm{B})$; o grupo com biomaterial está com o tecido primário ao redor do biomaterial sendo substituído por tecido secundário $(\mathrm{C})$; e o grupo com biomaterial associado à TLBI está num estágio mais avançado em comparação ao que não foi irradiado (D).

FIGURA 21. Diferença Diferença entre as médias de número de osteoblastos entre os grupos. O grupo GV apresenta um numero superior de osteoblastos se comparado com o controle (GC), porem menor se comparado ao GL e GVL. Sendo que GL e GVL não apresentam diferença estatística entre si.

FIGURA 22. Microscopia eletrônica de varredura com aumento original de 500X (as setas pretas indicam tecido ósseo e as setas brancas indicam partículas do biomaterial). O grupo no qual foi aplicada a vitrocerâmica apresenta início de pequena neoformação óssea no sétimo dia (A); o grupo em que foi aplicado a vitrocerâmica associada à TLBI pode-se observar um incremento na formação óssea com relação ao não submetido à irradiação, aos 7 dias (B); no $13^{\circ}$ dia observa-se uma quantidade maior de tecido ósseo e há indícios de absorção do biomaterial (C); com a combinação da aplicação do biomaterial com a TLBI nota-se que a formação óssea foi superior que na ausência do estímulo da radiação laser.. 


\section{SUMÁRIO}

1. RESUMO

2. ABSTRACT

3. LISTA DE FIGURAS

4. LISTA DE TABELAS

5. LISTA DE SIGLAS

6. INTRODUÇÃO................................................................................................................14

7. REVISÃO DA LITERATURA................................................................................17

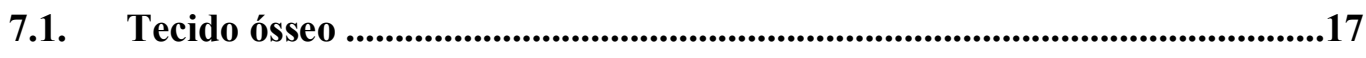

7.2. Biomateriais................................................................................................................. 20

7.3. Laser ......................................................................................................................... 22

7.3.1. Física do laser.....................................................................................................22

7.3.2. Estado da arte..........................................................................................................24

7.3.3. Interação do laser com o tecido ósseo...............................................................25

8. OBJETIVOS.................................................................................................................... 29

8.1. Geral ..................................................................................................................... 29

8.2. Específicos.....................................................................................................29

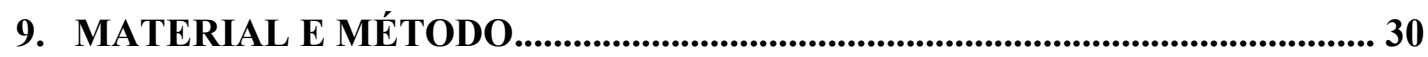

9.1. Caracterização do material ............................................................................... 30

9.2. Modelo experimental.................................................................................................34

9.3. Animais experimentais ..................................................................................... 34

9.4. Grupos experimentais ........................................................................................ 34

9.5. Procedimento experimental ........................................................................ 36 
9.6. Procedimento cirúrgico................................................................................. 38

9.7. Emissor laser de baixa intensidade........................................................... 41

9.8. Procedimento de irradiação.................................................................. 41

9.9. Preparação das amostras para análise dos dados.................................... 42

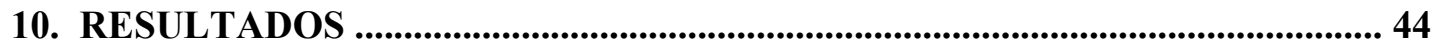

10.1. Análise de microscopia óptica com luz polarizada...................................... 44

10.2. Análise de microscopia de luz comum...................................................50

10.3. Análise de microscopia eletrônica de varredura............................................ 57

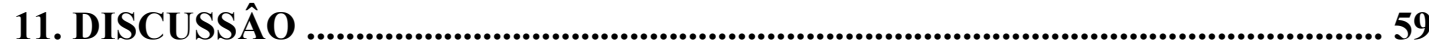

11.1. Análise de microscopia óptica com luz polarizada...................................59

11.2. Análise de microscopia de luz comum....................................................61

11.3. Análise de microscopia eletrônica de varredura............................................64

11.4. Considerações finais.................................................................................................65

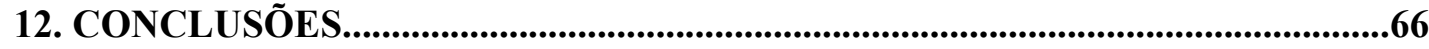

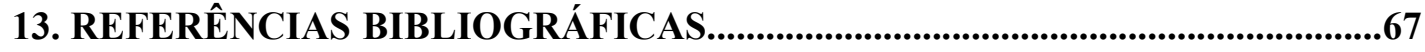




\title{
6. INTRODUÇÃO
}

\author{
Os implantes são dispositivos médicos feitos de um ou mais materiais \\ intencionalmente inseridos dentro do corpo. CONCENSUS CONFERENCE OF THE \\ EUROPEAN SOCIETY FOR BIOMATERIALS (1986).
}

Segundo Zavaglia et al (1986), os implantes sintéticos recebem a designação especial de biomateriais ou materiais biomédicos e podem ser compostos por metais e suas ligas, polímeros, cerâmicos ou compósitos.

Para que os materiais possam realizar suas funções, precisam possuir pelo menos duas propriedades: a biocompatibilidade e biofuncionalidade. A primeira é a capacidade de um material desencadear uma resposta apropriada do hospedeiro em uma aplicação específica e a segunda está relacionada ao conjunto de propriedades, que dá a um determinado dispositivo a capacidade de desempenhar uma função semelhante a qual está substituindo. Como exemplo dos materiais sintéticos atualmente considerados bioativos são o biovidro e os compostos da família dos fosfatos de cálcio como a hidroxiapatita, (BOSCHI. 1996).

Devido à necessidade de recuperação dos defeitos ósseos de grandes dimensões provocados por traumas, infecções, e malformações, é de grande interesse desenvolver materiais com características biológicas aceitáveis e que possam ser usados como substitutos dos tecidos ósseos. Frequentemente é utilizado o enxerto ósseo autógeno, ou seja, é retirado o tecido ósseo do próprio paciente para em seguida realiza-se o enxerto no local de interesse. Os maiores problemas deste tratamento é o volume ósseo a ser retirado do sítio doador, o desconforto no pós-operatório, e o alto custo, devido a necessidade de uma segunda cirurgia, o que encarece o binômio custo beneficio da cirurgia (RAY E HOLLOWAY,1957). 
As cerâmicas podem ser utilizadas como revestimento para próteses metálicas melhorando assim, a interação da superfície do implante com o organismo (ROLLO 1978), o que torna ainda mais importante o estudo de materiais bioativos como o biovidro e seus derivados.

O biovidro biogran ${ }^{\circledR *}$ com hidroxiapatita foi utilizado com sucesso em cavidades cirúrgicas em mandíbulas de macacos (CANCIAN et al, 1999).

$\mathrm{O}$ biovidro de composição: $45 \% \mathrm{SiO}_{2}, 24,5 \% \mathrm{Na}_{2} \mathrm{O}, 24,5 \% \mathrm{CaO}$ e $6 \% \mathrm{P}_{2} \mathrm{O}_{5}$ (biovidro genérico) mostrou-se um biomaterial não citotóxico e biocompatível com características de material de preenchimento e de material osteocondutor (REYES, 2000).

A vitrocerâmica baseada no biovidro acima descrito foi previamente preparada para ser avaliada no presente trabalho. Buscando a cristalinidade, o biovidro foi recozido em cuba de inox acima de sua temperatura de transição vítrea, $620^{\circ} \mathrm{C}$ por 30 minutos e mantido a $790^{\circ}$ C por 60 minutos.

Uma vez que estes tipos de implantes são utilizados no intuito de viabilizar o reparo ósseo, é relevante o fato de se tentar combiná-los com outras técnicas bioestimulantes.

O estimulo do reparo ósseo é alcançado tanto com sustâncias químicas, como pela utilização de ultra-som, emprego de campos eletromagnéticos, e pela radiação laser de baixa intensidade (GJELSVIK, 1973).

O laser de baixa intensidade apresentou resultados promissores na década de 60 , quando Mester e colaboradores iniciaram as pesquisas descrevendo seus primeiros resultados clínicos. Então, descobriu-se que esta irradiação estimulava a proliferação celular e também a vascularização dos tecidos injuriados.

\footnotetext{
* Biogran é marca registrada da BIOMET 3i, Inc.
} 
O seu efeito estimulante, utilizado inicialmente em cicatrização de feridas cutâneas, e atualmente, este recurso terapêutico é utilizado no reparo de diversos tecidos biológicos (MESTER et al. 1985).

A laserterapia de baixa intensidade tem sido estudada como estimulante do reparo ósseo com resultados promissores. (KHADRA, et al 2004; PINHEIRO \& GERBI. 2006. GARAVELLO et al. 2004; NICOLA, et al. 2003).

Karu (1988) sugeriu um mecanismo de ação diferente para os comprimentos de onda emitidos no visível e no infravermelho próximo, já que alguns autores tinham observado in vitro diferenças significativas quando trabalhavam com ambos. Com o passar do tempo essas diferenças foram confirmadas in vivo por outros pesquisadores (ALMEIDA-LOPES et. al. 2001).

O mecanismo de ação do laser no processo de reparação tecidual ainda não está totalmente esclarecido, entretanto sua ação aumenta o $\mathrm{Ca}^{+2}$ intracelular (KARU et al 1995)

Foram realizados estudos demonstrando melhor interação osso-implante utilizando-se LTBI com diodo de Arsenieto de gálio aluminizado (GaAlAs) em tíbias com implantes de titânio (KHADRA et al. 2004)

A melhor interação com implantes devido à laserterapia também foi obtida com sucesso em enxertos ósseos autógenos em ratos, com o estímulo mostrando-se dosedependente (DA SILVA, CAMILLI. 2006).

A literatura discute superficialmente a interação do biovidro no estado amorfo ou mesmo cristalino sob a influência da radiação laser de baixa intensidade com o tecido ósseo, porém a presença de cristalinidade trará benefícios no que diz respeito à bioatividade e osteocondução do material. E os fatores supracitados nos levam a crer que a LTBI, poderia ser empregada a fim de interagir de forma positiva no reparo ósseo em combinação com a utilização do vitrocerâmico elaborado a partir do vidro bioativo com composição em 
porcentagem de peso $45 \% \mathrm{SiO}_{2}, 24,5 \% \mathrm{Na}_{2} \mathrm{O}, 24,5 \% \mathrm{CaO}$ e $6 \% \mathrm{P}_{2} \mathrm{O}_{5}$, em perfurações de tíbias de ratos.

\section{REVISÃO DA LITERATURA}

\subsection{Tecido ósseo}

O osso é um tecido conjuntivo especializado mineralizado composto por $33 \%$ de colágeno e $5 \%$ de fibras não colagenosas, como osteocalcina, osteoctina, sialoproteínas, proteoglicanas e proteínas morfogenéticas ósseas. Os $67 \%$ restantes compõe-se de mineral, principalmente cristais de hidroxiapatita $\left(\mathrm{Ca}_{10}\left(\mathrm{PO}_{4}\right)_{6}(\mathrm{OH})_{2}\right)$ (TEN CATE 2001).

Macroscopicamente, é classificado como compacto e trabecular (Figura 1), o osso compacto é um tecido denso, bem vascularizado e mineralizado, o qual compõe o córtex dos ossos longos, HALL (1990). Já a classificação histológica do osso o divide em dois tipos, osso primário: embrionário, imaturo, isotrópico ou osteóide; e osso secundário: maduro, anisotrópico ou lamelar. Os dois possuem os mesmos tipos celulares apresentando, porém, diferentes organizações das fibrilas de colágeno quando analisados sob microscopia de luz polarizada (BUSER et al 1999). 


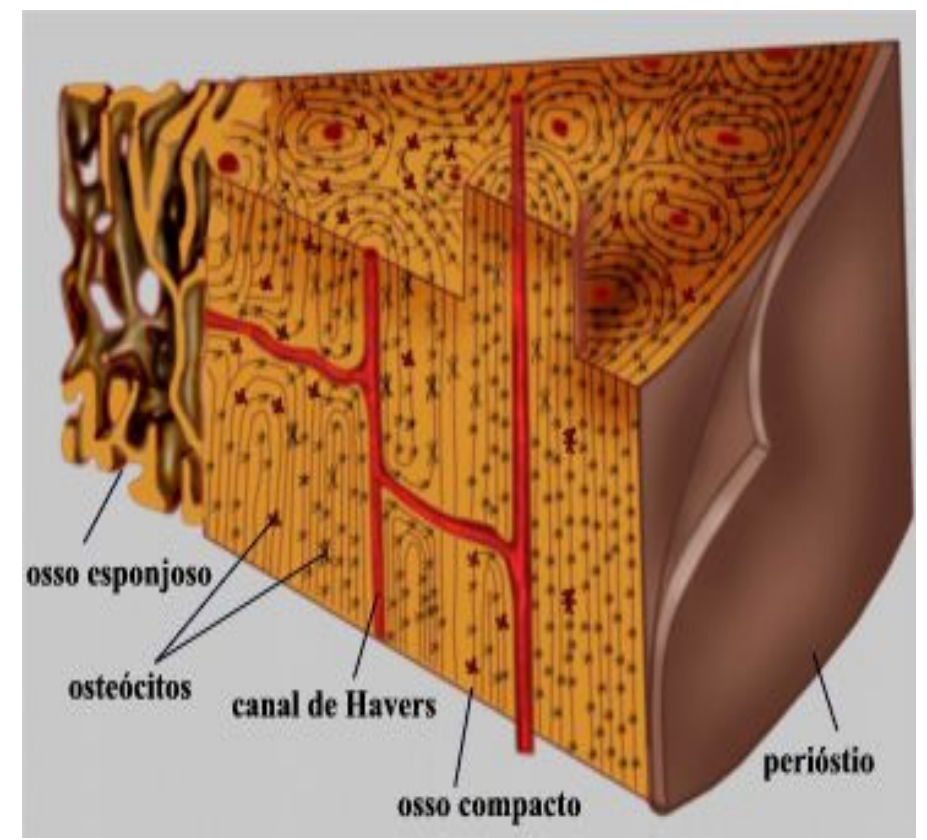

Figura 1. Osso compacto e trabecular (esponjoso).

O tecido ósseo secundário substitui gradativamente o tecido ósseo primário pela deposição gradual das fibras colágenas modelando a forma trabecular do osso primário em lamelas dispostas paralelamente umas as outras, formando ângulos retos que definem pequenos espaços medulares, o chamado osso esponjoso. Quando as fibras colágenas encontram-se dispostas em camadas concêntricas em torno de capilares sanguíneos e nervos, denominamos de canal de Havers, constituindo o chamado osso compacto (GARTNER e HIATT 2003).

A análise das fibras de colágeno é possível graças à propriedade deste tecido conhecida como anisotropia óptica no que refere a birrefringência de forma textural, através da utilização de luz polarizada em microscopia ótica. A microscopia de luz polarizada possibilita a quantificação em níveis de precisão elevados, permitindo a determinação exata da ordem molecular, da direção da vibração, de momento de transição e de variação nos estados de agregação molecular (VIDAL 1987a). Quando um feixe de luz natural incide num 
polarizador ideal, é transmitido apenas o seu componente com campo paralelo ao seu eixo de transmissão. No microscópio de luz polarizada há um segundo polarizador idêntico ao primeiro, o analisador, com eixo de transmissão orientado verticalmente. Desse modo, a irradiância é máxima quando os eixos de transmissão entre Polarizador e Analisador são nulos, é mínima ou ausente quando essa angulação é de $90^{\circ}$, segundo a Lei de Malus (VIDAL 1987b). Estudos mostram a utilização de um microscópio de luz polarizada para examinar a organização e agregação das fibras de colágeno (JÓSZA \& KANNUS 1997, ARRUDA et al 2007).

O componente celular do tecido conjuntivo é constituído por fibroblastos e fibrócitos, além de células ósseas específicas. As células que participam da osteogênese, ou seja, os processos de formação do osso são: osteócitos, osteoblastos e osteoclastos.

Os osteócitos e osteoblastos são células uninucleadas de origem mesenquimal, os osteoblastos são encontrados em grande número nas superfícies formadoras de osso na vida adulta. Os osteócitos, encontrados dentro das lacunas, são simples osteoblastos incorporados pela matriz óssea. Os osteoclastos com origem monócito-macrófago são células multinucleadas (seis a doze núcleos) encontradas ao longo da superfície do osso. Produzem depressões de reabsorção recortadas conhecidas como lacunas de Howship, local onde esta sendo reabsorvido ativamente o osso mineralizado, (COTRAN et al 1994).

A função do tecido ósseo é de sustentação e proteção dos órgãos do corpo. Também serve como alavanca para os músculos, impulsionando a movimentação, e fisiologicamente apresenta a função de reservatório mineral, principalmente de íons cálcio. (KATCHBURIAN e ARANA, 1999).

A formação do tecido ósseo pode-se dar de duas maneiras, intramembranosa e endocondral. Embora histologicamente um osso não se diferencie do outro, a ossificação intramembranosa se faz diretamente dentro de um tecido mesenquimatoso, ou seja, células 
progenitoras diferenciam-se em osteoblastos, que secretam matriz óssea formando uma malha de espículas e trabéculas ósseas. De outra maneira na ossificação endocondral, ocorre um adensamento de células mesenquimais, que se diferenciam em células cartilaginosas formando um molde de cartilagem hialina. Por fim, o molde de cartilagem cresce servindo de esqueleto estrutural para o desenvolvimento do osso, e posteriormente é reabsorvido.

\subsection{Biomateriais}

A busca por novos materiais sintéticos para o tratamento de alterações ósseas incentiva o estudo de uma técnica apoiada no desenvolvimento tecnológico, ainda pouco explorado, a do biomaterial.

Biomateriais são materiais desenvolvidos para uso em áreas da saúde com finalidade de substituir a matéria viva cuja função foi perdida, neste caso o tecido ósseo. Um biomaterial é qualquer substância sintética ou natural que pode ser utilizada para substituição total ou parcial de qualquer tecido, ou órgão do organismo. Excluem-se aqui os fármacos (GUASTALDI, 2004).

Segundo Hench (1998), dependendo do tipo de implante, pode haver quatro tipos diferentes de resposta do hospedeiro. Se o material é tóxico, o tecido ao seu redor morre. Se o material é não tóxico e biologicamente inativo (quase inerte), um tecido fibroso de espessura variável é formado. Se o material é não tóxico e biologicamente ativo (bioativo), uma ligação interfacial é formada. E, por último, se o material é não tóxico e se dissolve, o tecido ao seu redor o substitui. 
Os materiais vítreos são, muitas vezes, didaticamente classificados juntamente com as cerâmicas quando são estudadas as propriedades relacionadas ao comportamento dos materiais em relação ao hospedeiro.

Zavaglia et. al. (1996) descrevem, baseados nos tipos de ligação, a seguinte classificação dos materiais cerâmicos: biocerâmicas bioinertes, biocerâmicas com superfície ativa e biocerâmicas absorvíveis.

As biocerâmicas com superfície ativa têm uma ligação estável com o hospedeiro. São recomendadas nos locais onde há a necessidade de se estimular o crescimento ósseo ou de outros tecidos, na forma de pó como preenchimento. Exemplos desta classe são a hidroxiapatita, os biovidros, o Ceravital ${ }^{\circledR \dagger}$ e outros vitrocerâmicos.

As biocerâmicas absorvíveis têm como exemplo o fosfato tricálcico e são usualmente biocompatíveis e de fácil absorção pelo metabolismo natural. Inicialmente, ela tem baixa porosidade, com o início da absorção a porosidade se eleva, podendo haver crescimento de tecido dentro dos poros.

Em escala da estrutura atômica, o que distingue os materiais vítreos dos materiais cristalinos é a ausência de periodicidade. Os vidros são normalmente formados pelo resfriamento de um material no estado líquido a alta temperatura. A taxa de resfriamento é extremamente importante para esta classe de materiais, uma vez que taxas excessivamente lentas permitem o rearranjo dos átomos que se encontram dispersos na fase líquida, provocando a cristalização do material.

Segundo Välimäki e Aro (2006) o biovidro desenvolvido em 1971 por Larry Hench na Universidade da Flórida - Gainsville, é o nome dado a uma série de composições de vidros baseados no sistema $\mathrm{SiO}_{2}, \mathrm{Na}_{2} \mathrm{O}, \mathrm{CaO}, \mathrm{P}_{2} \mathrm{O}_{5}$ e que permitem a ligação do tecido ósseo a esses materiais, por meio da deposição de uma camada de hidroxicarbonatoapatita (HCA)

\footnotetext{
$\dagger$ Ceravital—é uma marca registrada de Ernst Leitz Wetzlar Gmbh, D- 6330 Wetzler-Germany.
} 
biológica, que permite a ligação interfacial. A ligação resultante é extremamente resistente, equivalendo ou superando a resistência mecânica do material de implante ou do tecido ligado ao implante.

É conhecido que as propriedades mecânicas dos vidros bioativos podem ser fortemente afetadas por transformação de fases (nucleação e crescimento de fases cristalinas) causada por tratamento térmico (LI et al. 1992).

MOURA e colaboradores (2006) obtiveram uma vitrocerâmica (Biosilicate ${ }^{\circledR}$ ) com maior bioatividade e propriedades mecânicas superiores ao do biovidro utilizado para a obtenção da mesma.

\subsection{Laser}

\subsubsection{Física do laser}

A palavra LASER é um acrônimo de "Light Amplification by Stimulated Emission of Radiation", ou seja, "Luz Amplificada pela Emissão Estimulada de Radiação”. O principio da emissão estimulada foi postulada por Albert Einstein, em 1917: a emissão estimulada da radiação é causada pela presença de um fóton indutor de energia interagindo com um átomo em seu estado excitado, resultando na liberação de dois fótons induzidos (BAXTER et al.1997).

Resumidamente, o laser funciona do seguinte modo. Um elétron de carga negativa órbita um núcleo de carga positiva, enquanto o átomo está em seu estado de repouso, que é o 
seu nível mais baixo de energia. Uma fonte extra de energia pode excitar o átomo e causar um salto de elétron para uma órbita mais alta, menos estável. O elétron quase que imediatamente retorna a sua órbita estável, e o átomo reassume seu estado normal de repouso. À medida que este processo ocorre, um pequeno feixe de energia extra, chamado fóton, é espontaneamente emitido. Se o fóton estiver perto de um outro átomo ainda no estado excitado, ele interage com este átomo. O fóton dispara o segundo átomo excitado para retomar o seu estado do repouso, e neste processo outro fóton de luz laser é emitido. Estes dois fótons de energia idêntica viajam juntos. Deste modo ocorre o processo de emissão estimulada e a energia a laser é inicialmente formada, sendo que esta luz apresenta particularidades que são a monocromaticidade e a coerência temporal e espacial. (ALMEIDA-LOPES, 1999).

Quando uma luz incidente atinge um determinado meio, esta luz pode sofrer algumas alterações, principalmente no que diz respeito a sua direção e interação; esta luz pode sofrer reflexão, absorção e transmissão. Quando uma luz laser atinge um determinado tecido, a reflexão vai depender do ângulo do feixe de luz laser incidente, pois quanto menor o ângulo formado entre o raio incidente e a superfície irradiada, maior a reflexão e menor a absorção. Portanto recomenda-se a utilização da luz laser incidente sempre de forma perpendicular a superfície a ser tratada com o objetivo de efetivar a absorção da luz no tecido irradiado, pois a luz só atuará nos tecidos de forma terapêutica se for absorvida e convertida em efeitos. (ALMEIDA-LOPES, 1997). 


\subsubsection{Estado da arte}

O primeiro laser da história foi construído em 1960 por Theodore maiman na Califórnia - USA (MAIMAN, 1960), era um laser de Rubi, operando em 694,3 nm. Em 1961 foi fundado, na Universidade de Cincinnati por Leon Goldman, o primeiro laboratório de laser para aplicações médicas (GOLDMAN, 1981), onde as primeiras experiências em animais foram realizadas.

Em 1962, Patel desenvolveu o primeiro laser com finalidade terapêutica, um HélioNeônio (He-Ne) com comprimento de onda de 632,8 nm .(PÖNTINEN, 1992).

As primeiras aplicações clínicas com laser operando em baixa potência foram relatadas em 1966, por Endre Mester de Budapeste, Hungria, que apresentou os primeiros relatos de casos clínicos sobre "Bioestimulação com Laser" de úlceras crônicas de membros inferiores usando lasers de rubi e de argônio, tendo publicado seus primeiros artigos em 1966 (MESTER, 1966). Ele produziu um grande volume de trabalhos científicos, clínicos e experimentais, tendo o laser de He-Ne, como tema central.

Em 1981, apareceu pela primeira vez o relato da aplicação clínica de um diodo laser de As-Ga-Al, publicado por Calderhea (1981), do Japão, que comparava a atenuação de dor promovida por um diodo laser e o laser de Nd: YAG, (Neodímio dopado com Ytrio e Alumínio), operando em $1064 \mathrm{~nm}$.

O comprimento de onda é extremamente importante, pois é ele quem define a profundidade de penetração no tecido alvo (BOURGELAISE, 1983; FULLER, 1983). Diferentes comprimentos de onda apresentam diferentes coeficientes de absorção para um mesmo tecido. Jacques (1995) resume os diferentes coeficientes de absorção para diferentes tecidos em função do comprimento de onda. As radiações emitidas na região do ultravioleta e 
na região do infravermelho médio apresentam alto coeficiente de absorção pela pele, fazendo com que a radiação seja absorvida na superfície, enquanto que na região no infravermelho próximo constata-se baixo coeficiente de absorção, implicando em máxima penetração no tecido e maior absorção em tecidos como o osso. (KARU, 1985; 1987).

\subsubsection{Interação da radiação laser com o tecido ósseo}

Segundo Baruska e colaboradores (1995), o efeito das radiações eletromagnéticas, como o laser de baixa intensidade, no reparo ósseo, tem sido estudado de maneira limitada. O laser é mais comumente estudado no reparo muscular, nervoso e de lesões cutâneas.

Os efeitos do laser de baixa intensidade ocasionam aceleração da neovascularização, aumento na síntese de ATP, redução do pH intracelular e alterações na proliferação, motilidade, e respiração celular, estimulando a fagocitose e a resposta imune, resultando em aceleração do processo de reparo tecidual (KITCHEN; PARTRIDGE, 1991; VEÇOSO 1993).

A ação da laserterapia de baixa intensidade (LTBI) tem início através da absorção da luz pelos cromóforos. Um importante cromóforo é o citocromo $\mathrm{C}$, enzima presente nas mitocôndrias das células, que faz parte da respiração celular. A mitocôndria por sua vez é responsável pela conversão do ADP em ATP, fornecendo energia para a célula manter suas atividades metabólicas (síntese de proteína; motilidade celular; manutenção do potencial de membrana e replicação celular). Devido à fotossensibilidade do citocromo $\mathrm{C}$ a energia da luz laser é absorvida e posteriormente transformada em energia (HARRIS, 1991; WILDEN, 1998; DAMANTE, 2003). 
Rigau (1996) analisando o efeito do laser de baixa potência sobre a cicatrização de feridas pôde verificar um aumento da síntese de colágeno e uma resposta diferenciada dos mastócitos e de mediadores biológicos durante o início da fase inflamatória, com conseqüente aumento da permeabilidade vascular e regulação da migração linfocitária local, fatores esses que levam uma reparação tecidual mais rápida nos períodos iniciais.

Karu (1988) sugeriu um mecanismo de ação diferente para os comprimentos de onda emitidos no visível e no infravermelho próximo, já que alguns autores tinham observado in vitro diferenças significativas quando trabalhavam com ambos. Com o passar do tempo essas diferenças foram confirmadas in vivo por outros pesquisadores (ALMEIDA-LOPES et. al. 2001).

Marino (2003) investigou o efeito da LTBI no reparo ósseo, e observou uma ação modulatória sobre o processo inflamatório. Possíveis alterações como reabsorção mais efetiva de exudatos, controle de fatores quimiotáticos, aumento na atividade fagocitária e aumento de vascularização, certamente contribuíram para uma neoformação óssea inicialmente mais ativa, ao fornecerem condições ambientais favoráveis.

A radiação laser de baixa intensidade tem apresentado efeitos positivos no reparo ósseo em animais, baseado em medidas morfogênicas, bioquímicas, radiográficas e ao microscópio eletrônico (LUGER et al., 1998).

Pretel e colaboradores (2007) demonstraram que o laser de $780 \mathrm{~nm}$ com $35 \mathrm{~mW}$ de potência estimulou o remodelamento ósseo em ratos entre 15 e 45 dias e modulou o processo inflamatório inicial.

Lirani et al (2004) demonstraram melhor efetividade da LTBI com $\lambda$ 780nm $30 \mathrm{~mW}$ de potência na fluência de $112,5 \mathrm{~J} / \mathrm{cm}^{2}$, na estimulação do reparo ósseo em tíbias de ratos, em comparação com o ultra-som de baixa intensidade, sendo que o mesmo já tem seus resultados comprovados no reparo ósseo. 
Trelles e Mayayo (1987) sugeriram que o laser de baixa intensidade pode modular a função de osteoblastos e osteócitos, promovendo assim aumento do metabolismo e reação mais rápida do calo ósseo. Em seu experimento, fraturas em tíbias de 30 ratos foram tratadas com laser He-Ne $(632,8 \mathrm{~nm}, 4 \mathrm{~mW}, 2,4 \mathrm{~J})$, por 10 minutos, com distância de 20 centímetros do foco de lesão, em dias alternados num total de 12 sessões, com início no pós-operatório imediato. Foram utilizados 30 animais como controle e submetidos a tratamento simulado. Foi observado ao microscópio óptico, no grupo tratado, um aumento na vascularização e formação mais rápida de tecido ósseo com uma densa rede trabecular quando comparado com o controle, que apresentou apenas tecido cartilaginoso e pobre vascularização, correspondendo assim a um estágio mais precoce do reparo.

Em um experimento realizado com ratos, a carga máxima suportada e a rigidez estrutural do calo da tíbia fraturada foram significativamente mais elevadas no grupo que recebeu tratamento com radiação laser de baixa intensidade. Outro achado foi que $21 \%$ das fraturas não tratadas evoluíram para pseudo-artose, fato que não ocorreu em nenhuma fratura do grupo tratado, sugerindo então uma influência positiva do laser no reparo ósseo. Os animais foram divididos em 2 grupos de 25 cada e sofreram fratura transversal total no terço médio da tíbia, acompanhada de fixação interna com fio de Kirschner intramedular. O grupo 1 foi tratado com LTBI He-Ne $(632,8 \mathrm{~nm})$, modo de emissão contínuo e potência de $35 \mathrm{~mW}$, imediatamente após a cirurgia a uma distância de $20 \mathrm{~cm}$ por $30 \mathrm{~min}$. diários $(10 \mathrm{~min}$. na área fraturada, 10 min. na área imediatamente inferior e $10 \mathrm{~min}$. na área imediatamente superior) por 14 dias consecutivos. Os animais foram sacrificados com 2, 4 e 6 semanas. Os calos foram testados por distração, sendo que com 2 semanas estavam muito imaturos. Com 4 semanas, a resistência do calo era bem próxima à da fratura completamente consolidada, e em 6 semanas as fraturas estavam consolidadas por completo (LUGER et al., 1998). 
A aplicação diária da LTBI por mais de sete dias produziu uma melhora na neoformação trabecular num estudo utilizando fraturas tibiais de ratos. Os osteoblastos ficaram dispostos lado a lado, de maneira que assemelhavam-se a um epitélio simples na periferia da trabécula óssea. Esta disposição é característica de osteoblastos ativamente engajados na síntese de matriz óssea. A laserterapia não só diminuiu o tempo de reparo como também produziu uma maior área de reparo ósseo (FREITAS et al., 2000).

Os efeitos da LTBI na osteointegração de dispositivo ósseo protético implantado, ainda não são claros. Em um estudo com 12 coelhos, pinos cilíndricos de hidroxiapatita foram parafusados distalmente em ambos os fềmures de cada animal. A partir do primeiro dia pósoperatório e por 5 dias consecutivos, o fêmur esquerdo dos animais receberam tratamento com LTBI através de um diodo de As-Ga-Al (780nm) utilizando dose de 300J/ $\mathrm{cm}^{2}, 1 \mathrm{~W}$ de potência, modo pulsado a $300 \mathrm{~Hz}$, por 10 minutos. O fêmur direito recebia tratamento placebo. Quatro ou oito semanas após a colocação do implante, analises histológicas e histomorfométricas avaliaram o contato osso-biomaterial. A histomorfometria mostrou maior grau de osteointegração na interface osso-hidroxiapatita no grupo tratado por $4(p<0.0005)$ e oito semanas $(\mathrm{p}<0.001)$. Estes resultados positivos parecem sustentar a hipótese que a LTBI pode ser considerada uma boa ferramenta para acentuar a interface osso-implante na cirurgia ortopédica (GUZZARDELLA et al., 2001). 


\section{OBJETIVOS}

\subsection{Geral}

O objetivo do presente estudo foi avaliar os efeitos provocados pela aplicação do compósito vitrocerâmico elaborado a partir do biovidro genérico de composição baseada em: $\% \mathrm{SiO}_{2}, 24,5 \% \mathrm{Na}_{2} \mathrm{O}, 24,5 \%$ de $\mathrm{CaO}$ e $6 \%$ de $\mathrm{P}_{2} \mathrm{O}_{5}$, após a verificação da presença de cristalinidade, em perfurações ósseas sob a influência de irradiação laser de baixa intensidade $\lambda$ 780nm, $30 \mathrm{~mW}$ de potência e dose $112,5 \mathrm{~J} / \mathrm{cm}^{2}$.

\subsection{Específicos}

- Comparar através dos cortes histológicos a presença de células e sua interação com o vitrocerâmico no foco lesionário entre os grupos;

- Comparar dentre os grupos a neoformação óssea ocorrida pós-lesão;

- Analisar a organização e maturação das fibras colágenas e comparar dentre os grupos;

- Verificar a biocompatibilidade e a bioatividade do biomaterial em questão;

- Avaliar a influência da terapia laser nos parâmetros descritos sobre a interação do tecido ósseo com o vitrocerâmico. 


\section{MATERIAL E MÉTODO}

\subsection{Caracterização do biomaterial}

Foi utilizada uma vitrocerâmica baseada no biovidro genérico, o biovidro $45 \mathrm{~s} 5$ padrão possui a composição: $45 \% \mathrm{SiO}_{2}, 24,5 \% \mathrm{Na}_{2} \mathrm{O}, 24,5 \%$ de $\mathrm{CaO}$ e $6 \%$ de $\mathrm{P}_{2} \mathrm{O}_{5}$. No entanto, a fonte de fósforo (P) utilizado na síntese do Genérico do Bioglass, foi $\mathrm{NaPO}_{3}$, A fração de moles de $\mathrm{P}$ utilizada corresponde, em equivalência de $6 \%$ de $\mathrm{P}_{2} \mathrm{O}_{6}$.

$\mathrm{O}$ biovidro foi fundido em cadinho de platina a $1340^{\circ} \mathrm{C}$ (mistura de fusão), buscando a cristalinidade foi aquecido em cuba de inox acima de sua temperatura de transição vítrea, a $620^{\circ} \mathrm{C}$ por 30 minutos e mantido à $790^{\circ} \mathrm{C}$ por 60 minutos. Este material teve a capacidade de preenchimento em perfurações ósseas e propriedades osteocondutoras testadas no presente estudo.

A análise térmica diferencial (figura 2) traz informações sobre o comportamento térmico do biovidro com a composição citada acima, fornecendo desta forma dados úteis para a realização do tratamento térmico para obtenção de cristalinidade. 


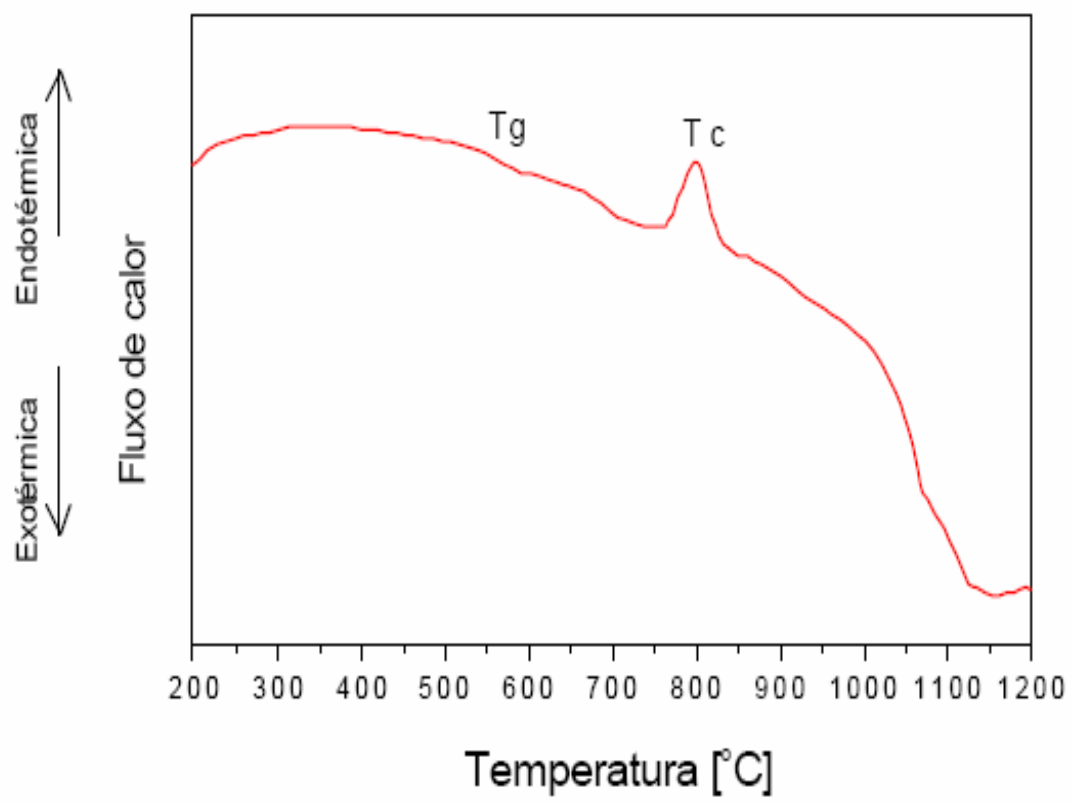

Figura 2. Análise térmica diferencial do biovidro genérico, evidenciando a temperatura de transição vítrea próximo de $620^{\circ} \mathrm{C}$ e a temperatura de cristalização próximo a $790{ }^{\circ} \mathrm{C}$.

Para caracterizar o vitrocerâmico utilizado no presente experimento, foi utilizado a técnica de Micro Raman e também a de Difração de Raios-X.

O Micro Raman foi realizado no Departamento de Física da Universidade Federal de São Carlos, utilizando o Espectrômetro duplo Jobin-Yvon U1000, dotado de lasers de argônio, titânio-safira e corante, fotomultiplicadora de Ga-As, e medidores de potência do laser.

O equipamento baseia-se em um monocromador e um microscópio com fotoanalizador, onde se observa as características da luz monocromática ao atravessar o corpo de prova, o laser utilizado possui comprimento de onda de $514 \mathrm{~nm}$, o qual atravessa o material e passa pelo analisador, onde são avaliadas as características da luz. Os picos formados no gráfico da amostra cristalizada estão presentes apenas em materiais que apresentam um grau 
de cristalinidade, já na amostra vítrea os picos não aparecem, o que caracteriza um material amorfo (figura 3).

A difração de Raios-X foi realizada no laboratório de cristalografia do IFSC-USP com equipamento Siemens, modelo D 5000 Kristofollex, utilizou-se método de varredura contínua com intervalo $2 \theta$.

No gráfico é visível a formação de picos que indicam o estado semicristalino e a formação de fases compatíveis com cristais de Silicato de Sódio e Cálcio enquanto na amostra vítrea os picos estão ausentes (figura 4), o que é característica de um material amorfo confirmando a espectroscopia Raman.

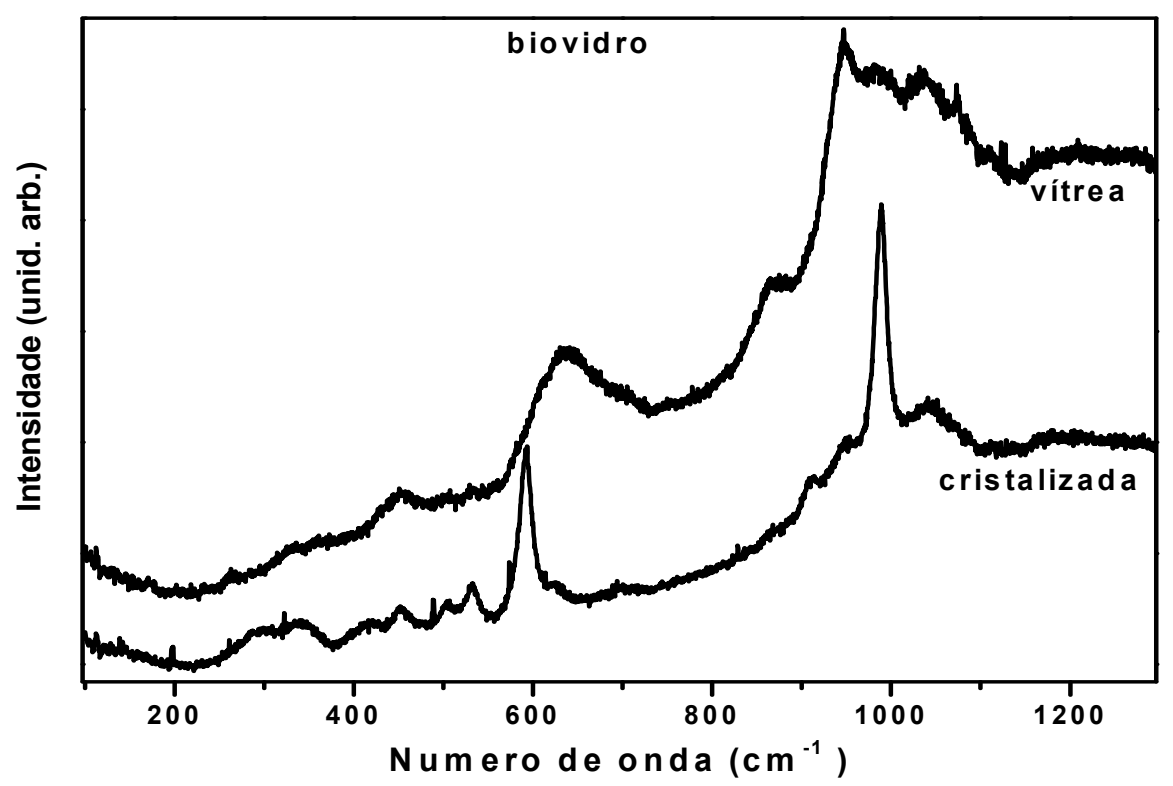

Figura 3. Espectroscopia Raman comparando as amostras antes e após o tratamento térmico, a cristalinidade é evidente e pode ser observada pela formação de picos de cristalinidade. 
A)

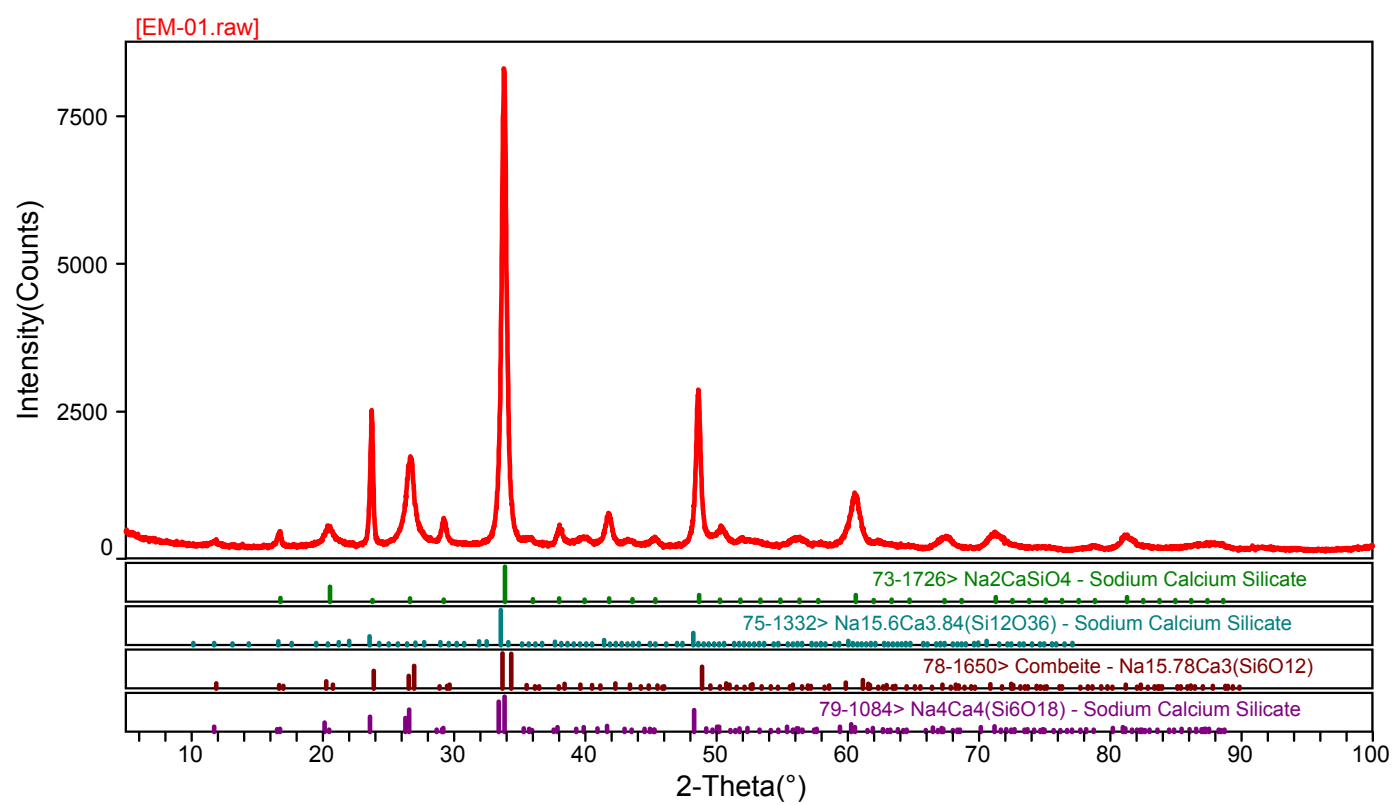

B)

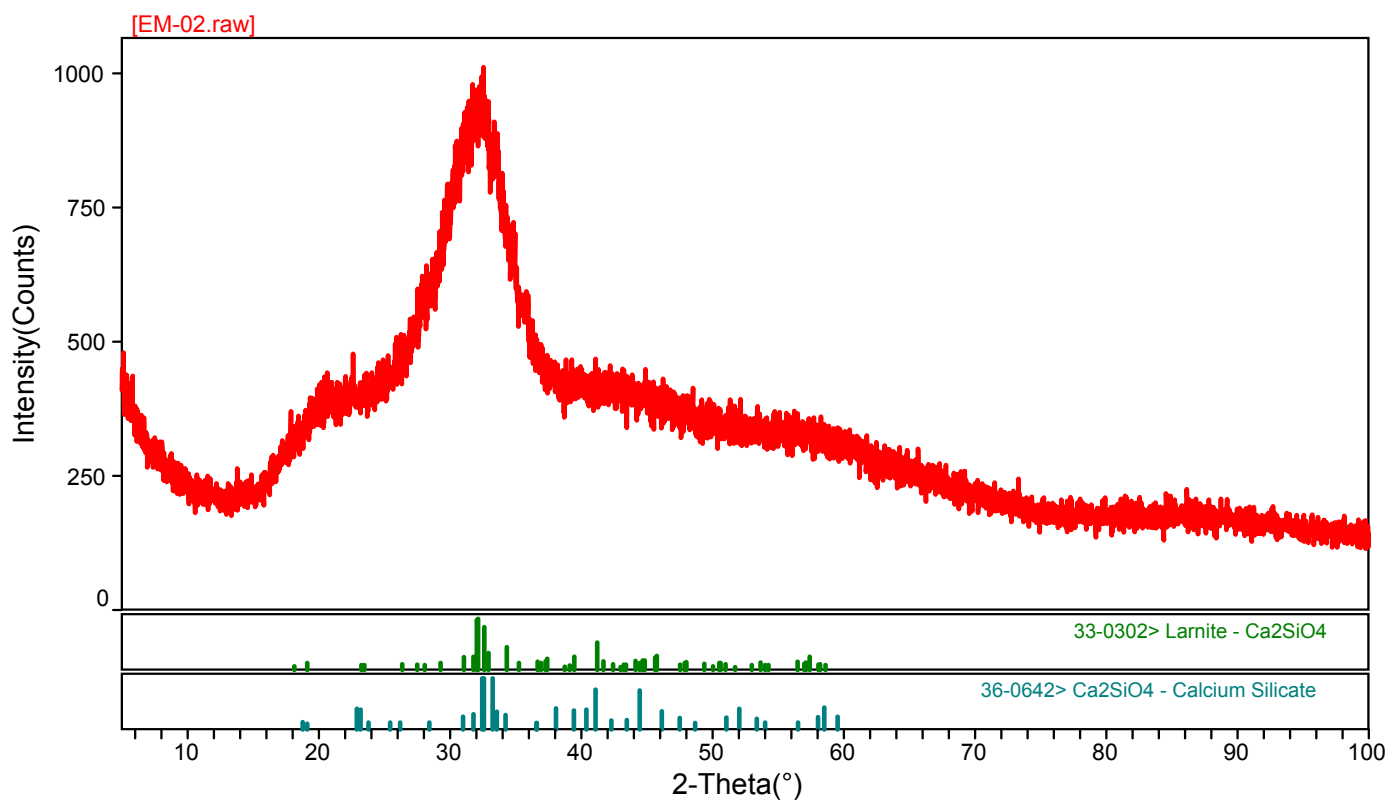

Figura. 4. A DRX evidencia picos de cristalinidade na amostra da vitrocerâmica, compatíveis com fases de silicato de sódio e calcio (A), já a amostra vítrea (B) não apresenta picos, característica de material amorfo. Destacando a eficiência do tratamento térmico empregado. 


\subsection{Modelo Experimental}

O modelo utilizado neste estudo foi baseado no experimento de REYES (2000), no qual foram realizadas duas perfurações na tuberosidade da tíbia de coelhos albinos da nova Zelândia, logo abaixo do tendão patelar. A tuberosidade da tíbia é normalmente escolhida por apresentar pouca mobilidade e pequena irrigação sangüínea.

\subsection{Animais Experimentais}

Foram utilizados 64 ratos machos da raça Wistar (Rattus norvegicus albinus) na idade adulta pesando entre 280 e 320 gramas. Estes permanecerão em gaiolas de polipropileno, agrupados em quatro indivíduos por gaiola, mantidos em ambiente higienizado a cada dois dias, com iluminação ciclo claro/escuro de 12 horas, recebendo água e ração balanceada $a d$ libitum.

\subsection{Grupos experimentais}

Os animais, com suas tíbias direitas perfuradas cirurgicamente foram divididos aleatoriamente em quatro grupos, dos quais um foi utilizado como controle e três submetidos 
a procedimento experimental de implante e/ou irradiação laser de baixa intensidade. Os grupos utilizaram 16 animais. Posteriormente, os animais de cada grupo foram subdivididos em dois subgrupos cada, de acordo com o tempo de vida antes da eutanásia, que ocorreu com 7 e 13 dias P.O..

\section{Grupo experimental $1(n=16)$}

Os animais não foram submetidos a nenhum procedimento após a cirurgia, permanecendo em suas gaiolas durante todo o período experimental, desta forma o reparo ósseo ocorre sem interferências. Grupo representado pela sigla GC.

\section{Grupo Experimental 2 ( $n=16)$}

Os animais tiveram a lesão submetida à aplicação de vitrocerâmico. Grupo representado pela sigla $\mathrm{GV}$. 


\section{Grupo Experimental 3 ( $n=16$ )}

Neste grupo os animais receberam desde o primeiro dia P.O. radiação laser infravermelho $\lambda 780 \mathrm{~nm}$, contínuo, potência $30 \mathrm{~mW}$ e fluência $112,5 \mathrm{j} / \mathrm{cm}^{2}$, resultando em um tempo de aplicação de 2,5 minutos. Grupo representado pela sigla GL.

\section{Grupo Experimental $4(n=16)$}

Os animais foram submetidos à aplicação de vitrocerâmico, e também à irradiação laser infravermelho $\lambda 780 \mathrm{~nm}$, contínuo, potência $30 \mathrm{~mW}$ e fluência $112,5 \mathrm{j} / \mathrm{cm}^{2}$, resultando em um tempo de aplicação de 2,5 minutos. Grupo representado pela sigla GVL.

\subsection{Procedimento Experimental}

O procedimento experimental passou por adaptações para se obter os presentes resultados, a começar pelo procedimento cirúrgico, que teve como objetivo uma lesão padrão, que possibilitasse a avaliação do comportamento osteocondutor da vitrocerâmica sob a influência da fotobiomodulação laser, e não provocasse refraturas facilmente.

Para tanto, foi realizado um estudo piloto em duas etapas, cada etapa utilizou quatro animais divididos em dois grupos. A primeira etapa foi destinada à padronização da lesão e a 
segunda para a padronização da técnica de aplicação do vitrocerâmico.

Neste piloto, utilizaram-se as mesmas condições de assepsia e anestesia que foram adotadas no procedimento cirúrgico definitivo. E após a cirurgia os animais permaneceram por sete dias em gaiola de polipropileno higienizadas a cada dois dias, agrupados em dois indivíduos por gaiola com ciclo claro/escuro de 12 horas, água e ração ad libitum.

Na primeira etapa dois dos animais foram submetidos à cirurgia onde foi utilizada uma broca de 2,5 milímetros, nos outros dois animais uma de dois milímetros.

Os animais com a perfuração de $2,5 \mathrm{~mm}$ tiveram a tíbia refraturada no período em que permaneceram na gaiola, os que possuíam perfuração de dois mm apresentaram uma lesão relativamente grande e que não causou problemas com relação à refraturas.

$\mathrm{Na}$ segunda etapa, todos os animais foram submetidos à perfuração de dois mm e os quatro animais foram divididos em dois grupos.

Um grupo foi submetido à colocação do vitrocerâmico com seu veículo utilizando para isto uma espátula, porém a hemorragia dificultava a colocação do biomaterial em questão no defeito experimentalmente criado.

No segundo grupo foi usado um porta-amálgama com dois milímetros de diâmetro na ponta, e este método obteve sucesso na colocação do vitrocerâmico no sítio de lesão, estancando a hemorragia no momento da aplicação.

Após a realização deste estudo piloto, a partir dos resultados obtidos, foi padronizado o diâmetro perfuração em 2 milímetros, que foi possível utilizando a própria broca, ou seja, quando a ponta da mesma se encaixasse na perfuração, tanto em diâmetro quanto em profundidade.

A perfuração ocupou uma área correspondente à aproximadamente $2 / 3$ do diâmetro da tíbia dos animais, o que permitiu a colocação do vitrocerâmico, sem, no entanto, causar possibilidade de refraturas. 
Para facilitar a colocação da vitrocerâmica na perfuração confeccionada, foi necessário utilizar um veículo líquido. No caso, o sangue do animal, o que permitiu a possibilidade do uso de um porta-amálgama.

O porta-amálgama foi escolhido por ter uma ponta com diâmetro de 2 milímetros, idêntico ao da lesão, por este motivo a vitrocerâmica com seu veículo preencheram a perfuração por completo estancando imediatamente a hemorragia causada pela perfuração.

O fio utilizado para sutura interna foi escolhido como sendo não reabsorvível, pelo motivo do fio absorvível causar um processo inflamatório inicial mais intenso, o que poderia prejudicar a avaliação das características da lesão.

\subsection{Procedimento cirúrgico}

Todo o procedimento foi realizado de acordo com as normas para a prática didáticocientífica da vivissecção de animais (lei 6638/08 de maio de 1979) e com os princípios éticos na experimentação animal (COBEA 1991) sob condições padrão de assepsia e sob anestesia geral, e foi aprovado pelo comitê de ética de experimentação animal da Universidade Federal de São Carlos - CCEA/UFSCAR através do parecer 006/2007

Antes do procedimento cirúrgico foi realizada a pesagem dos animais e determinada a dose de anestésicos. Esta composta da combinação de cloridrato de Ketamina 10\% e cloridrato de Xilazina $2 \%$, com dose proporcional ao peso do animal e utilizada em cada indivíduo de todos os grupos com aplicação intraperitoneal.

A pele circunjacente à tuberosidade da tíbia da pata direita foi previamente tricotomizada e limpa com álcool etílico iodado (Figura 5). Foi realizada uma pequena incisão 
longitudinal sobre a pele, e uma incisão na musculatura tornando possível a perfuração da tíbia (Figura 6).

Para realizar as perfurações $10 \mathrm{~mm}$ abaixo do platô tibial, foi utilizada uma broca com motor de alta rotação para cirurgias ( Figura 7).

O local onde foi confeccionado o defeito foi irrigado constantemente com soro fisiológico para refrigerar o mesmo e evitar necrose óssea por queimadura.

A aplicação da vitrocerâmica está representada pela Figuras 9.

Ao final do procedimento, a pele e o músculo foram suturados usando fio poliamida monofilamento 3.0 não reabsorvível (Figura 10), e então a pele foi limpa com solução de álcool iodado, proporcionando desta forma higienização local.

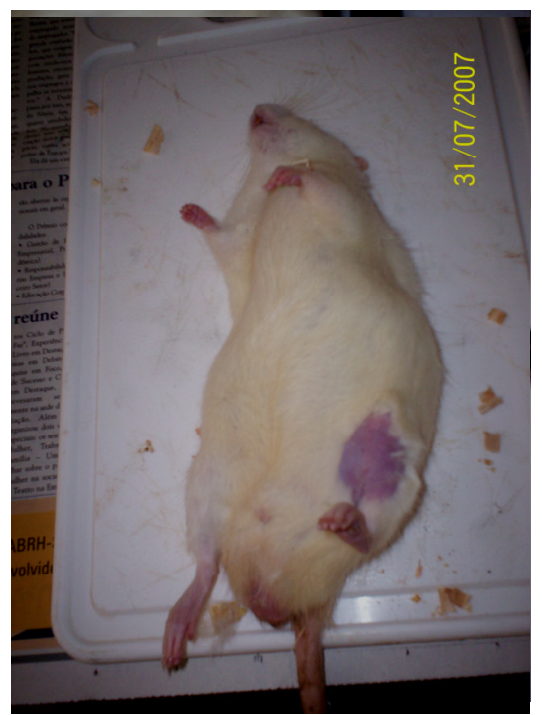

Figura 5. Animal com a pele tricotomizada.

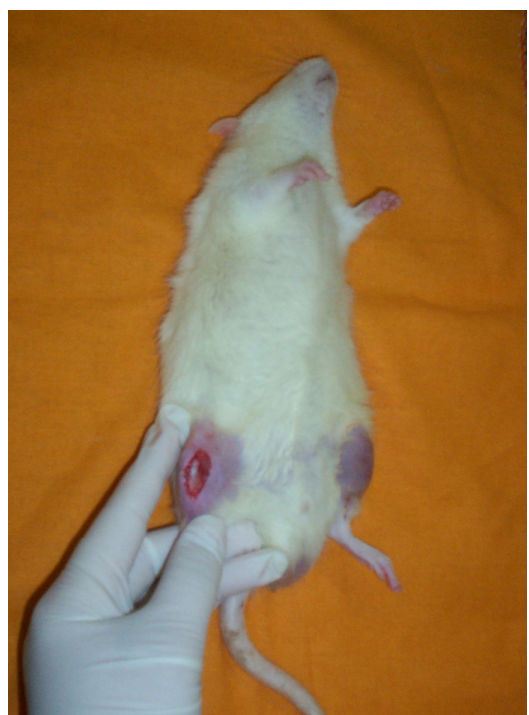

Figura 6. Exposição da tíbia para perfuração. 


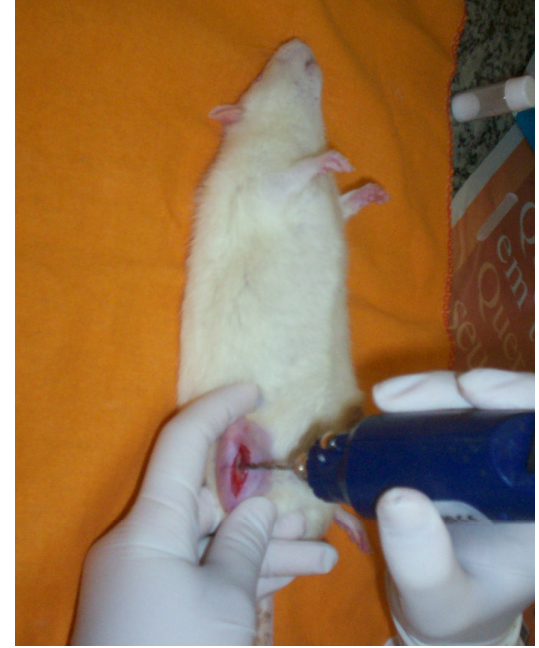

Figura 7. Perfuração sendo realizada com a broca, esta era irrigada com soro fisiológico para evitar danos por queimadura.

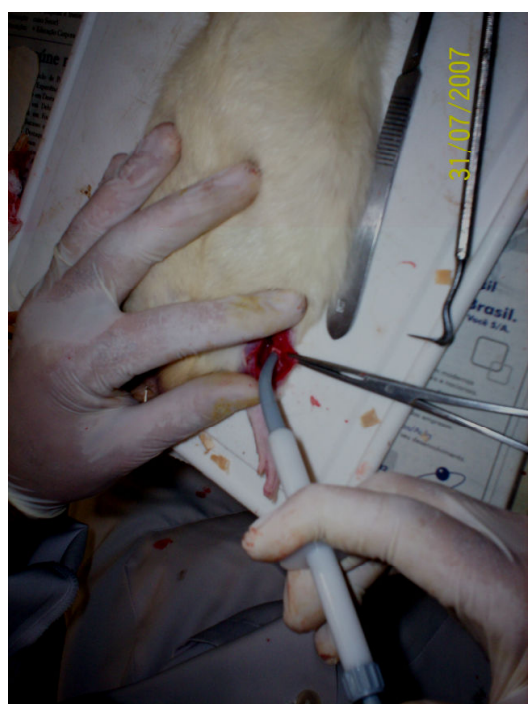

Figura 9. Aplicação do vitrocerâmico com auxílio do porta-amalgama.

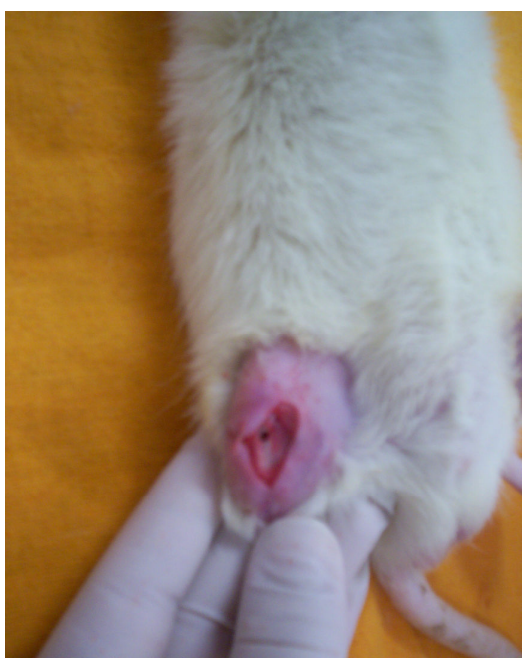

Figura 8. Perfuração de $2 \mathrm{~mm}$ de diâmetro realizada na tíbia.

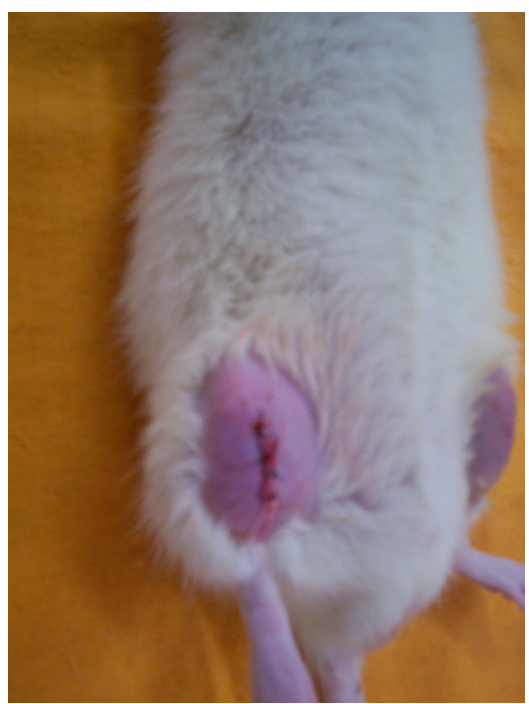

Figura 10. Sutura externa (pele) higienizada com álcool iodado. 


\subsection{Emissor de laser de baixa intensidade}

O equipamento que foi utilizado neste experimento é um modelo comercial de procedência da MM Optics, classe 3B, denominado TWIN LASER (fig. 11). O comprimento de onda utilizado foi $780 \mathrm{~nm}$. A área do spot é de $4 \mathrm{~mm}^{2}$ e a irradiância utilizada foi $750 \mathrm{~mW} / \mathrm{cm}^{2}$. O equipamento utilizado foi aferido no Grupo de Óptica da Universidade de São Paulo - USP, Campus de São Carlos, para se obter alta confiabilidade na intensidade efetiva da emissão laser.

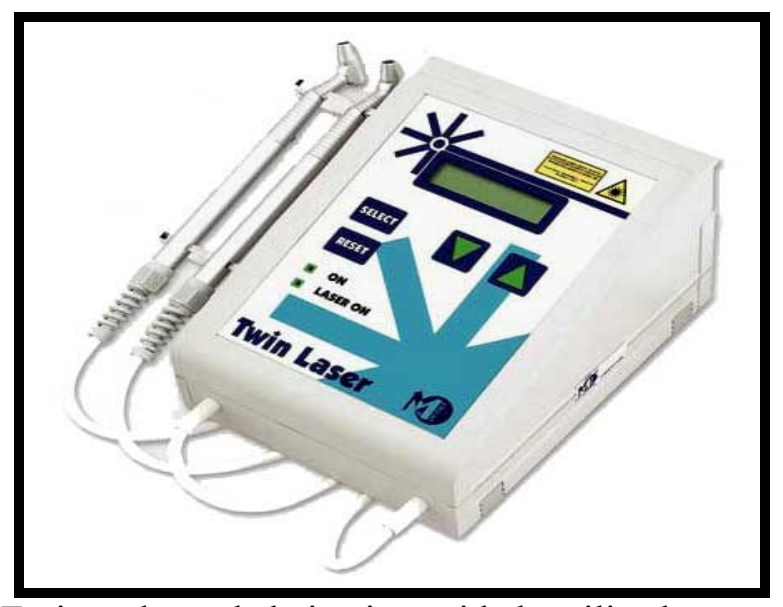

Figura 11. Emissor laser de baixa intensidade utilizado no experimento.

\subsection{Procedimento de irradiação}

A terapia laser terá seu início 24 horas após a lesão, e foi realizada durante 12 dias consecutivos. Todo o procedimento foi efetuado num período do dia predeterminado, e a pele dos animais permaneceu tricotomizada durante todo o período de tratamento. Os parâmetros empregados no experimento foram: modo contínuo de emissão, potência de $30 \mathrm{~mW}$, dose de $112,5 \mathrm{~J} / \mathrm{cm}^{2}$. Resultando deste modo em um tempo de aplicação de 150 segundos e energia total no ponto de: $4,5 \mathrm{~J}$. 
A irradiação foi executada com técnica de contato, onde a probe ficará posicionada de forma perpendicular à pele, irradiando-se um único ponto, de maneira transcutânea sobre o foco lesionário, localizado $10 \mathrm{~mm}$ abaixo do platô tibial.

\subsection{Preparação das amostras para análises de dados}

A eutanásia dos animais foi realizada por deslocamento cervical sob anestesia, os animais ficaram em jejum de 12 horas antes deste procedimento para assegurar uma melhor ação do anestésico.

Logo após a eutanásia, a tíbia direita de cada animal foi retirada e colocada em solução de fixação à base de formalina a $10 \%$ durante 24 horas, posteriormente ficaram sob água corrente 24 horas e depois foram descalcificadas em solução de Morse.

Depois de descalcificadas as peças foram cortadas em um pedaço de aproximadamente 10 milímetros, o foco de lesão situava-se no centro. Depois de cortadas elas foram neutralizadas em uma solução de sulfato de sódio seguido do procedimento para desidratação em banhos seriados de álcool e diafanização em xilol. Posteriormente, foi feito o procedimento de inclusão em parafina.

Realizaram-se dois tipos de cortes longitudinais, um com $7 \mu \mathrm{m}$, direcionado à análise das características das fibras colágenas: microscopia de força atômica para determinar a maturação e interação com o biomaterial em questão, lâminas coradas com HE observadas à microscopia de luz comum para quantificar a presença de células no foco de lesão, e Picro Sirius sob luz polarizada averiguando o estado organizacional do colágeno depositado.

Outro tipo de corte, de aproximadamente $10 \mu \mathrm{m}$ foi feito para análise de microscopia 
eletrônica de varredura (MEV) para avaliar a interação do biovidro com o tecido ósseo.

Os cortes de 10 micrômetros foram colocados em lâminas e as mesmas foram cortadas para serem coladas nos suportes para MEV, posteriormente as mesmas foram cobertas com uma fina camada de ouro no equipamento Batzers SCD 50, para permitir a análise da MEV, realizada no equipamento Digital Scanning Microscope DSM 960 marca ZEISS, foram feitas fotos com 500X de aumento no centro da lesão para verificar somente o tecido neoformado e sua interação com o vitrocerâmico.

As lâminas coradas com Picro Sirius foram observadas e fotografadas com um aumento de 100X para avaliação qualitativa, possibilitando assim a visualização de quase todo o foco de lesão, bem como seu limite. As figuras apresentadas no texto são a representação do padrão alcançado em cada grupo.

As fibras colágenas mais espessas e fortemente birrefringentes apresentam-se coradas de tons de laranja a vermelho, o que corresponde ao colágeno mais anisotrópico (JUNQUEIRA, BIGNOLAS e BRENTANI, 1979). Para avaliação quantitativa, foi utilizado o software ImageJ, onde é possível quantificar a intensidade do brilho de birrefringência calculando a intensidade em "pixels" da cor dada pelo Picro Sirius Red sob luz polarizada, para realizar a análise, somente a área com tecido neoformado foi selecionada e submetida à quantificação, despresando-se a área com tecido intacto. Foram realizadas 4 medidas por lâmina, pois em cada lâmina havia 4 cortes de um mesmo animal, a média aritmética foi calculada resultando na média por animal, estas médias foram agrupadas nos respectivos grupos e submetidas à análise estatística.

As lâminas coradas com H\&E foram observadas e fotografadas em dois aumentos: 100X para observar o aspecto geral e possibilitar a visualização do limite da lesão, e 500X para se observar as células e sua interação com o biomaterial. As figuras apresentadas no texto são a representações do padrão alcançado em cada grupo. 
Esta contagem celular foi realizada utilizando o programa image tool versão 3.0, onde foi realizada a contagem de osteoblastos em 3 campos aleatórios dentro da área lesada em cada corte, cada lâmina possua 4 cortes de um mesmo animal resultando em 12 valores por animal, foi calculada a média aritmética destes valores e os mesmos foram submetidos a analise estatística.

A análise estatística foi realizada utilizando o programa Statística, os dados foram submetidos aos testes de Levene e Shapiro-Wilks onde foram estabelecidas respectivamente a homogeneidade e a normalidade dos dados de ambas as análises quantitativas.

Posteriormente foi aplicado o teste ANOVA unicaudal com Post hoc. Tukey em ambos os casos. Os valore de significância considerado foi $\mathrm{p}<0,05$.

\section{RESULTADOS}

Durante todo o experimento não houve perdas amostrais e as lesões ficaram todas padronizadas, o que garantiu a qualidade da avaliação subseqüente.

\subsection{Análise de microscopia de luz polarizada}

Abaixo estão dispostas imagens submetidas à coloração de Picro Sirius, utilizadas para uma descrição qualitativa do padrão dos grupos aos 7 dias. O grupo controle apresenta pouca anisotropia, porém o colágeno depositado já se encontra numa fase de reorganização. 
O grupo irradiado encontra maior anisotropia das fibras colágenas, o que evidencia um melhor estado organizacional das mesmas.

Na presença da vitrocerâmica as partículas do biomaterial possivelmente estão agindo como um retardo por não terem sido reabsorvidas em uma escala que permitisse maior formação óssea, mas o colágeno começa a ser depositado às margens da perfuração.

A TLBI também aumentou a anisotropia do colágeno na presença do implante vitrocerâmico, embora as partículas do biomaterial ainda estejam servindo como uma retardo, pelo fato de ainda não terem sido suficientemente reabsorvidas.
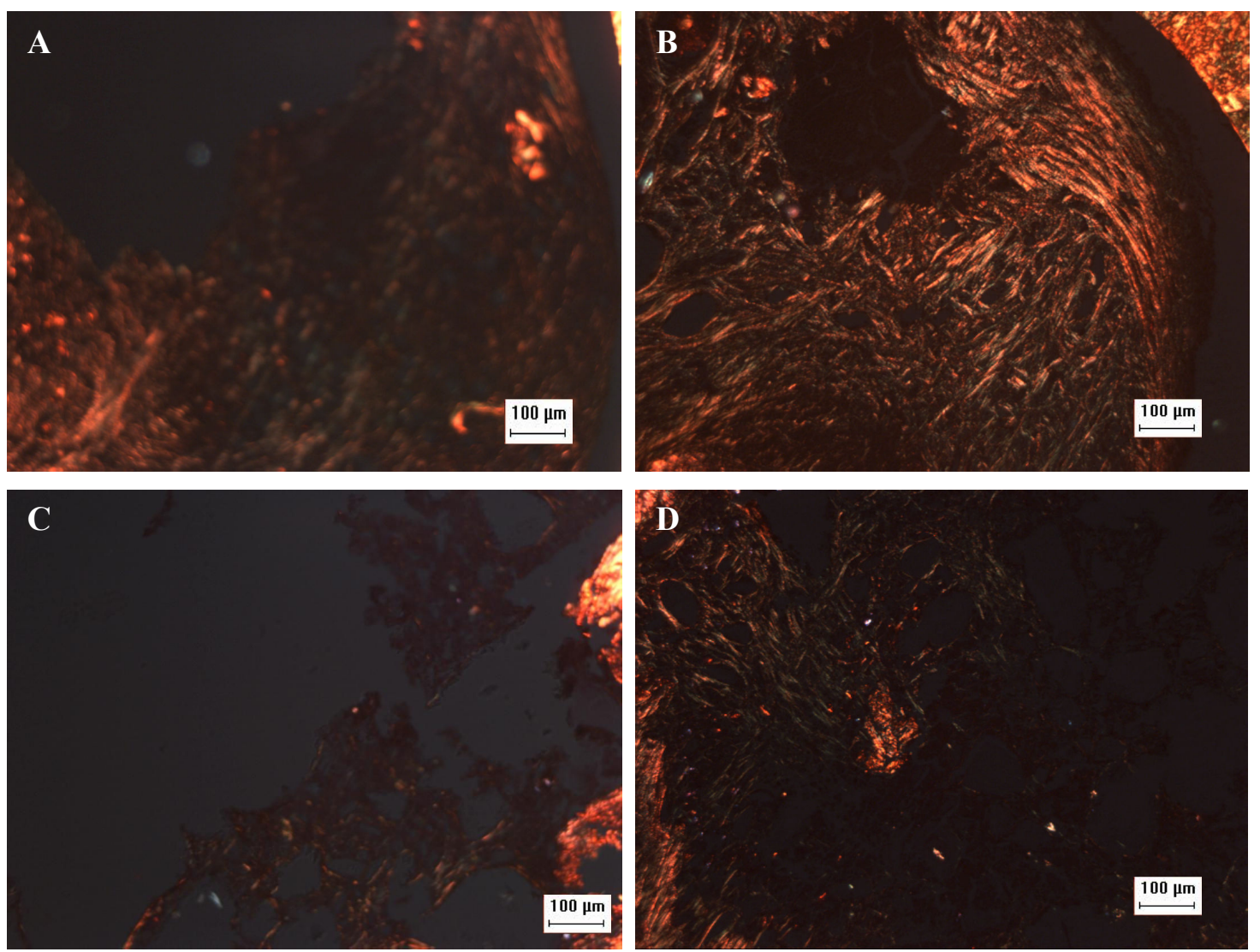

Figura 12. Exemplares de lâminas de animais sacrificados no $7^{\circ}$ dia coradas com Picro Sirius sob luz polarizada (aumento original de 100X), a intensidade do brilho de birrefringência é proporcional à organização das fibras colágenas. $O$ grupo controle apresenta pouco brilho em comparação com o grupo irradiado (A); o grupo apenas irradiado apresenta brilho moderado (B); o grupo com biomaterial tem pouco de brilho de birrefringência quando comparado com os demais grupos $(\mathrm{C})$; já o grupo com associação de biomateriais com a LTBI apresenta um brilho superior quando comparado com o grupo que apenas recebeu o vitrocerâmico brilho (D). 
$\mathrm{Na}$ análise quantitativa os valores alcançados pelos grupos estão descrito na tabela 1 , onde as médias e os respectivos desvios referentes à organização tecidual dos grupos com sete dias submetidos à análise do brilho de birrefringência com a coloração Picro Sirius Red sendo que os valores de $\mathrm{p}$ estão dispostos na tabela 2, onde os valores em vermelho são estatisticamente significantes $(\mathrm{p}<0,05)$.

Tabela 1. Médias em "Pixels" da intensidade do brilho de birrefringência aos 7 dias.

\begin{tabular}{c|c|c} 
& MÉDIAS & DESVIO PADRÃO \\
\cline { 1 - 1 } GC & 67,76 & $\mathbf{8 , 0 8 5 4 5 9 6 1 2}$ \\
GV & 43,985 & 3,129061932 \\
\cline { 1 - 1 } GL & 121,4625 & 9,828375465 \\
GVL & 54,4325 & 2,365748145
\end{tabular}

Tabela 2. Valores de p para diferença entre as médias dos grupos aos 7 dias.

\begin{tabular}{c|c|c|c|c} 
& GC & GV & GL & GVL \\
\cline { 1 - 1 } & M=67,760 & M=43,985 & M=121,46 & M=54,432 \\
\cline { 1 - 1 } GC & & $\mathbf{0 , 0 0 0 1 6 5}$ & $\mathbf{0 , 0 0 0 1 6 5}$ & $\mathbf{0 , 0 0 2 3 3 3}$ \\
\cline { 1 - 1 } GV & 0,000165 & & $\mathbf{0 , 0 0 0 1 6 5}$ & $\mathbf{0 , 0 1 9 7 0 3}$ \\
\cline { 1 - 1 } GL & 0,000165 & $\mathbf{0 , 0 0 0 1 6 5}$ & & $\mathbf{0 , 0 0 0 1 6 5}$ \\
\cline { 1 - 1 } GVL & 0,002333 & $\mathbf{0 , 0 1 9 7 0 3}$ & $\mathbf{0 , 0 0 0 1 6 5}$ &
\end{tabular}


A figura 13 ilustra o gráfico com as médias da intensidade do brilho de birrefringência dado pela coloração Picro Sirius Red.

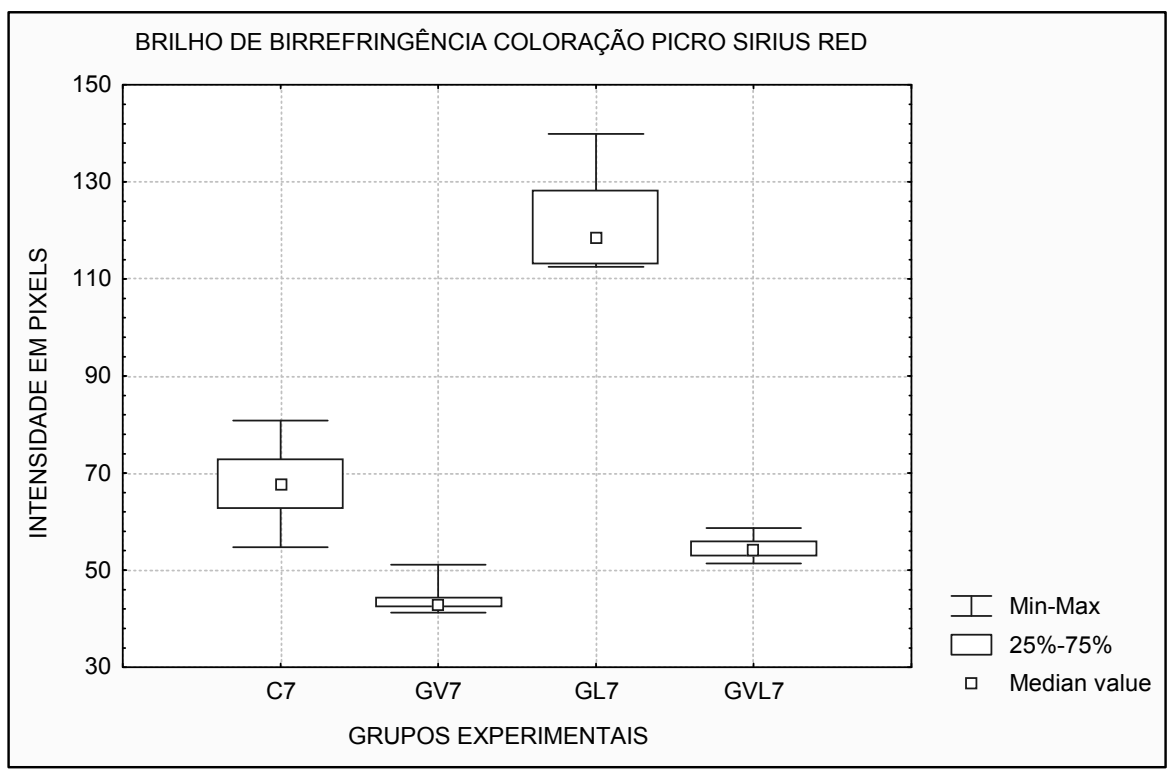

Figura 13. Diferença entre as médias do brilho de birrefringência apresentado pelos grupos, o brilho foi quantificado em "pixels" pelo software imageJ. Os grupos com vitrocerâmico apresentam um atraso na formação de tecido anisotrópico (GV e GVL), em comparação com o controle (GC), esta diferença diminui sob a influencia da radiação laser (GVL), e o grupo apenas irradiado (GL) apresenta maior formação de tecido anisotrópico, sugerindo uma fotoestimulação do reparo ósseo.

Abaixo as imagens submetidas à coloração de Picro Sirius no $13^{\circ}$ dia mostram que neste período a reabsorção do material já é evidente, com as fibras colágenas sendo depositadas com uma anisotropia moderada. O grupo controle, no qual os animais permaneceram na gaiola durante todo o período experimental pós-cirúrgico, já apresenta uma alta anisotropia e os grupos irradiados têm a organização melhorada em comparação com os não irradiados. 

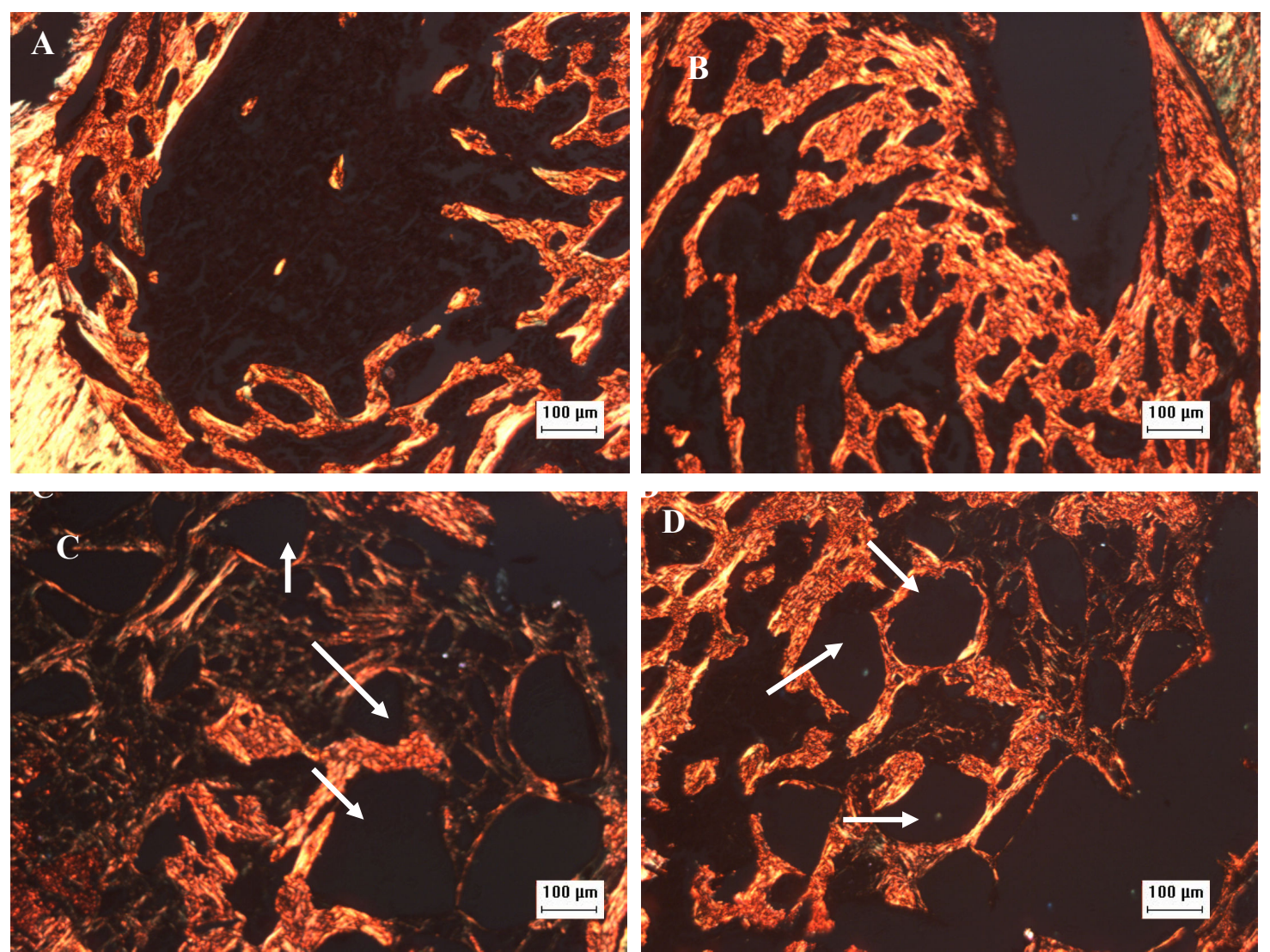

Figura. 14 exemplares de lâminas de animais sacrificados no $13^{\circ}$ dia, coradas com Picro Sirius sob luz polarizada (aumento original de 100X) no controle o brilho é moderado e as fibras localizam-se às margens da lesão $(\mathrm{A})$; no grupo irradiado com laser há um brilho mais intenso e difuso pelo sítio de lesão (B), no grupo com vitrocerâmica as fibras ficam em torno das partículas e apresentam moderado brilho(C) e finalmente no grupo com vitrocerâmica irradiado percebe-se um incremento no brilho e na espessura das fibras colágenas (D) (a seta branca indica a localização das partículas do vitrocerâmico).

$\mathrm{Na}$ análise quantitativa os valores alcançados pelos grupos aos 13 dias estão descrito na tabela 3, onde as médias e seus respectivos desvios, referentes à organização tecidual dos grupos com sete dias submetidos à análise do brilho de birrefringência com a coloração Picro Sirius Red. sendo que os valores de p estão dispostos na tabela 4, onde os valores em vermelho são estatisticamente significantes $(\mathrm{p}<0,05)$. 
TABELA 3. Médias em "Pixels" da intensidade do brilho de birrefringência aos 13 dias.

\begin{tabular}{c|c|c} 
& MEDIAS & DESVIO PADRÃO \\
\cline { 1 - 1 } & 124,6388 & 10,12411469 \\
\cline { 1 - 1 } GV & 115,85 & 5,184575337 \\
GL & 154,8938 & 5,716274855 \\
GVL & 153,35 & 5,128631118
\end{tabular}

TABELA 4. Valores de p para diferença entre as médias dos grupos aos 13 dias.

\begin{tabular}{c|c|c|c|c} 
& GC & GV & GL & GVL \\
\cline { 1 - 1 } & M=125,18 & M=115,85 & M=154,89 & M=140,87 \\
\cline { 1 - 1 } GC & & 0,012115 & 0,000165 & 0,000186 \\
\cline { 1 - 1 } GV & 0,012115 & & 0,000165 & 0,000165 \\
\cline { 1 - 1 } GL & 0,000165 & 0,000165 & & 0,000291 \\
\hline
\end{tabular}



dias.

Na figura 15 o gráfico ilustra com as médias em pixels e os desvios dos grupos aos 13

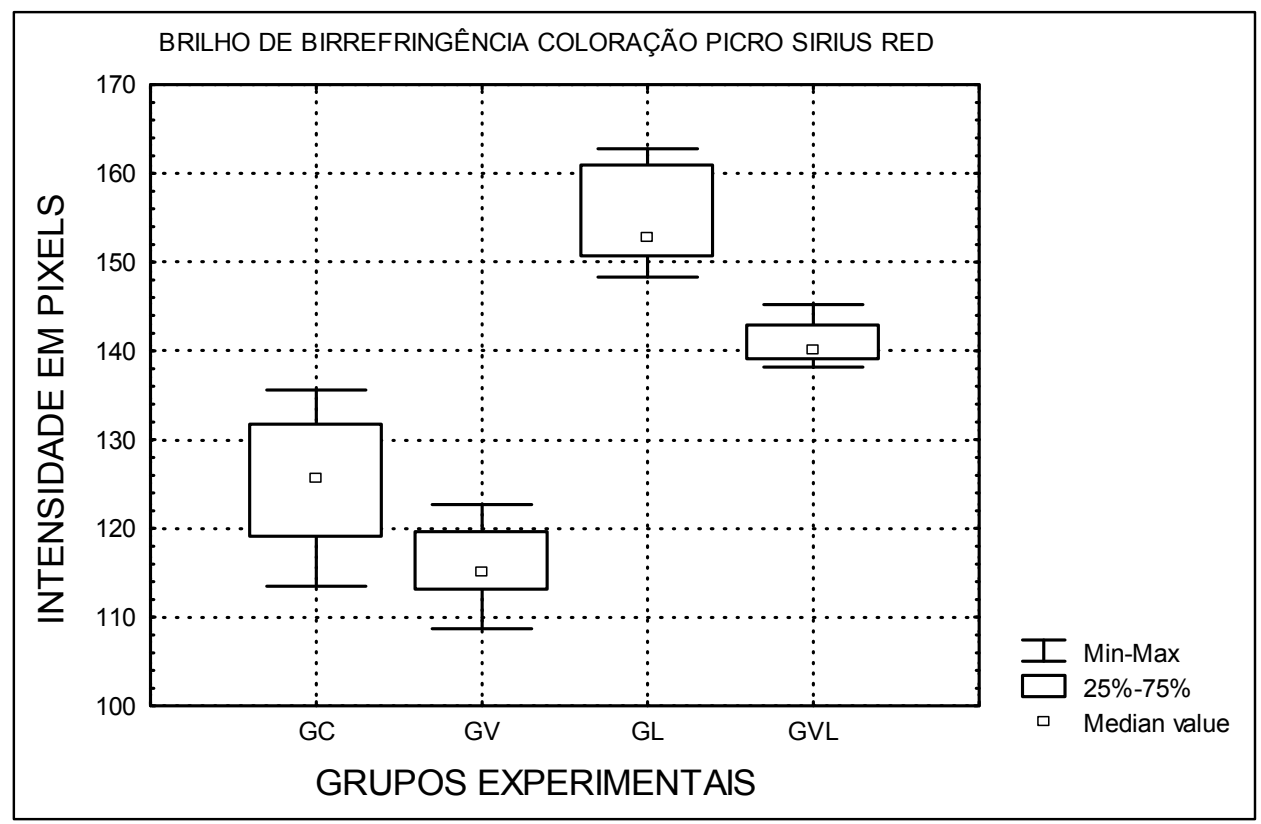

Figura 15 Diferença entre as medias dos grupos, o brilho foi quantificado em "pixels" utilizando o software imageJ. O GV apresenta anisotropia um pouco inferior ao controle (GC), os grupos irradiados apresentam grande incremento na anisotropia (GVL e GL), sendo o GL o grupo com maior quantidade de tecido anisotrópico.

\subsection{Análises de microscopia de luz comum}

As lâminas coradas com H\&E foram observadas e fotografadas em dois aumentos: 100X para observar o aspecto geral e possibilitar a visualização do limite da lesão, e 500X para se observar as células e sua interação com o biomaterial. As figuras apresentadas são as representações do padrão apresentado por cada grupo.

Abaixo estão os exemplares com sete dias, onde se observa deposição de colágeno em todos os grupos com intensa presença de osteoblastos, porém, no grupo apenas irradiado já é 
possível observar osso secundário em meio a osso primário, e quando comparados os grupos com vitrocerâmica, observa-se que quando sob influência do laser tecido em torno do biomaterial tem melhor organização.
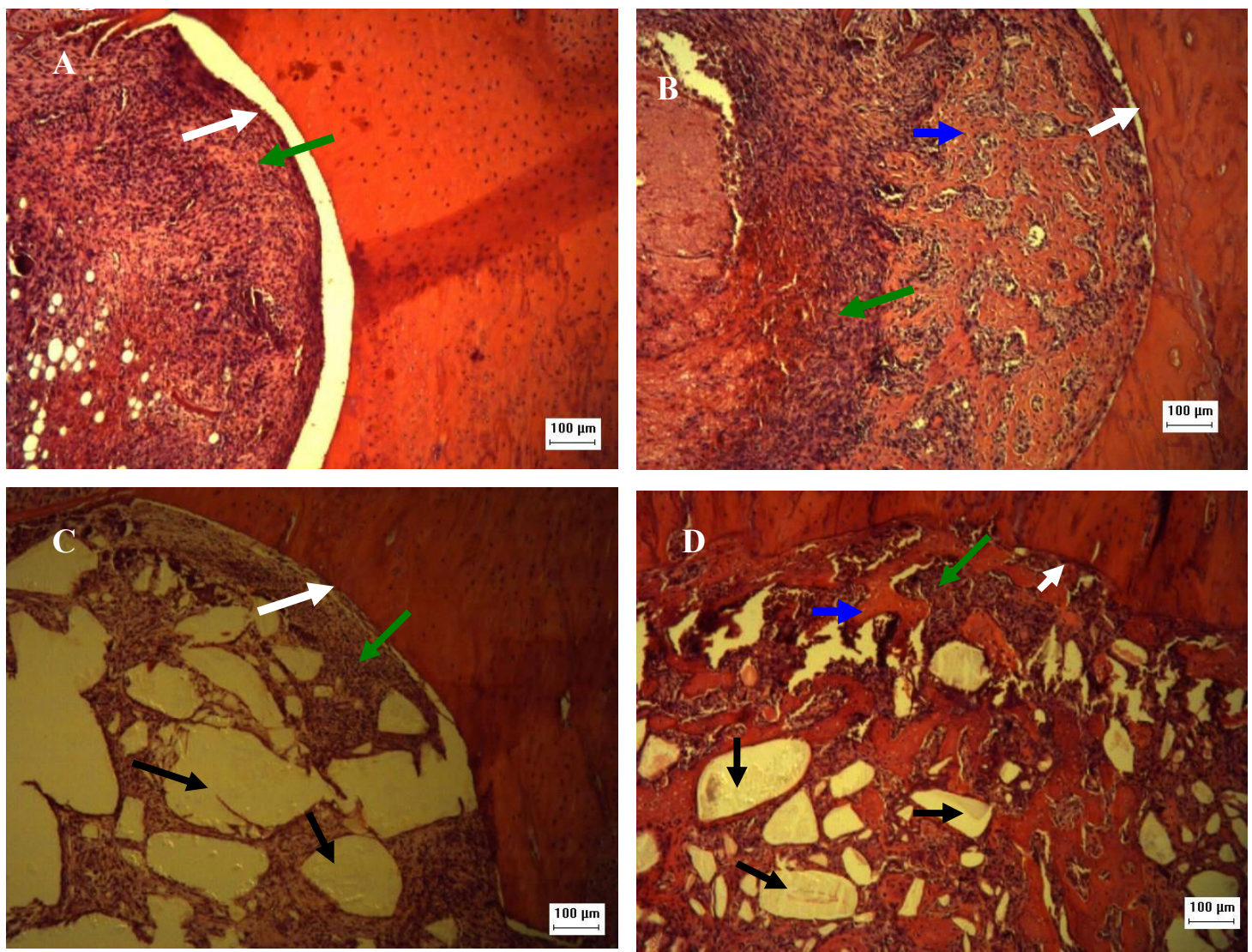

Figura 16. Exemplares de lâminas coradas com H.E. de animais sacrificados no $7^{\circ}$ dia (100X). A seta branca indica o limite da lesão; a azul, osso secundário; a verde, osso primário; e a preta, partículas de biomaterial. No grupo controle há formação de tecido ósseo primário (osteóide) (A); no grupo irradiado pode-se ver a formação de osso secundário (lamelar) (B); no grupo com biomaterial percebe-se o tecido primário ao redor das partículas de vitrocerâmica (C); já os animais que receberam a aplicação do biomaterial associado à LTBI há uma maior concentração de células osteoblásticas em torno do material com intensa deposição de osso primário (D). 

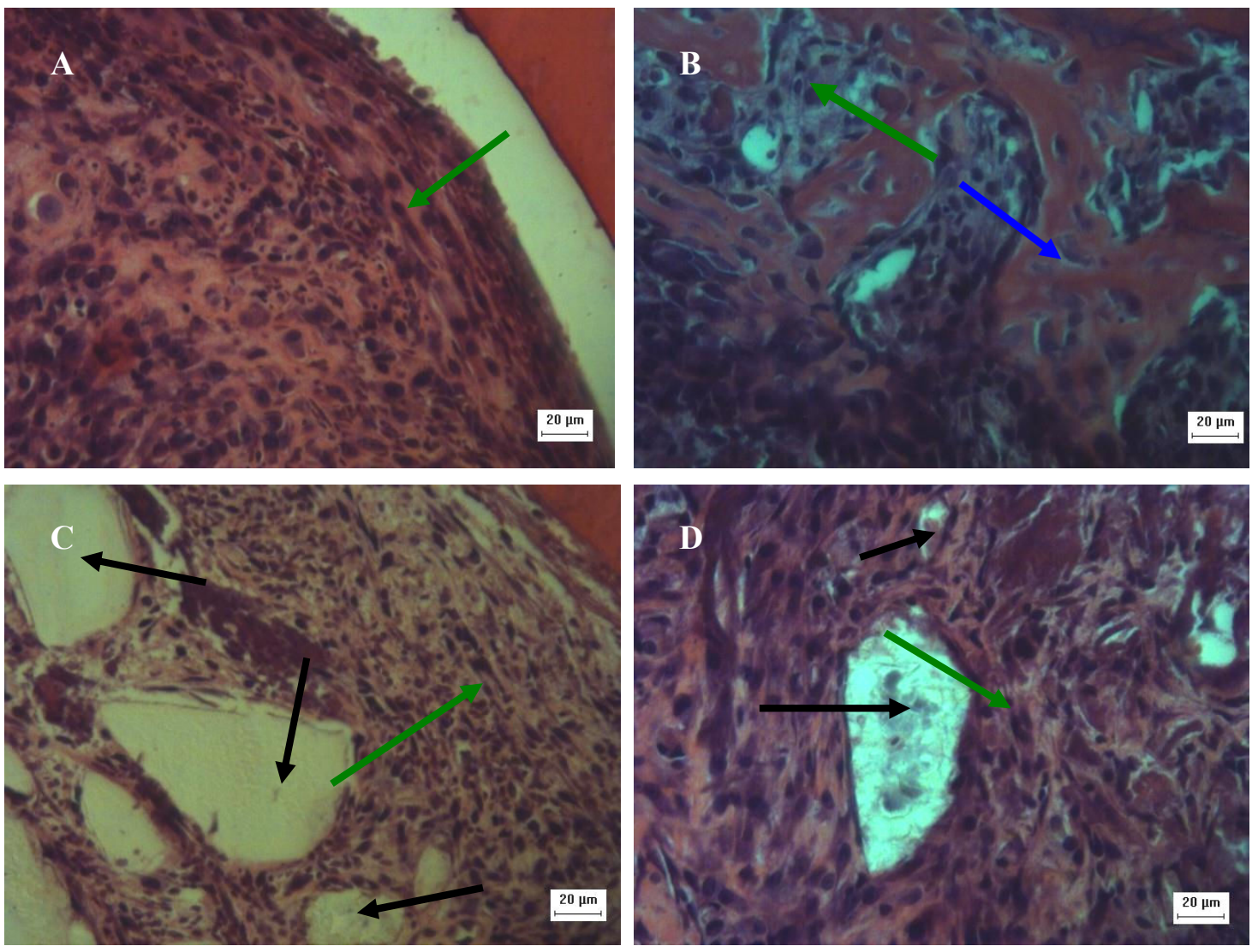

Figura 17. Exemplares de lâminas coradas com H.E. de animais sacrificados aos 7 dias (500X). A seta preta indica partículas do biomaterial, a azul tecido secundário e a verde tecido primário. $\mathrm{O}$ grupo controle apresenta grande número de osteoblastos dando origem a tecido osteóide (A); o grupo irradiado apresenta formação de lamelas ósseas (tecido secundário) e vários vasos sanguíneos; o grupo com vitrocerâmica apresenta osteoblastos dando origem a tecido ósseo primário em torno do biomaterial (C); o grupo com vitrocerâmica irradiado apresenta osteoblastos invadindo o biomaterial (D).

Os dados quantitativos referentes à contagem de osteoblastos estão dispostos na tabela 5, e os valores de p para a diferença das médias entre os grupos estão na tabela 6 , onde os valores marcados em vermelho apresentam diferença estatisticamente significante $(p<0,05)$. E a figura 20 ilustra o gráfico da diferença entre as médias do número de osteoblastos entre os grupos. 
TABELA 5. Médias do número de osteoblastos por grupo e seus respectivos desvios.

\begin{tabular}{l|r|c} 
& MÉDIA & DESVIO PADRÃO \\
\cline { 1 - 1 } GC & 67,1375 & 2,812694438 \\
\cline { 1 - 1 } GV & 72,75 & 2,434865793 \\
GL & 92,25 & 2,645751311 \\
\cline { 1 - 1 } GVL & 100,75 & 2,314550249
\end{tabular}

TABELA 6. Valores de p para diferença entre as médias do numero de osteoblastos dos grupos.

\begin{tabular}{|c|c|c|c|c|}
\hline & GC & GV & GL & GVL \\
\hline & $M=67,137$ & $M=72,750$ & $M=92,250$ & $M=100,75$ \\
\hline GC & & 0,000933 & 0,000165 & 0,000165 \\
\hline GV & 0,000933 & & 0,000165 & 0,000165 \\
\hline GL & 0,000165 & 0,000165 & & 0,000165 \\
\hline GVL & 0,000165 & 0,000165 & 0,000165 & \\
\hline
\end{tabular}

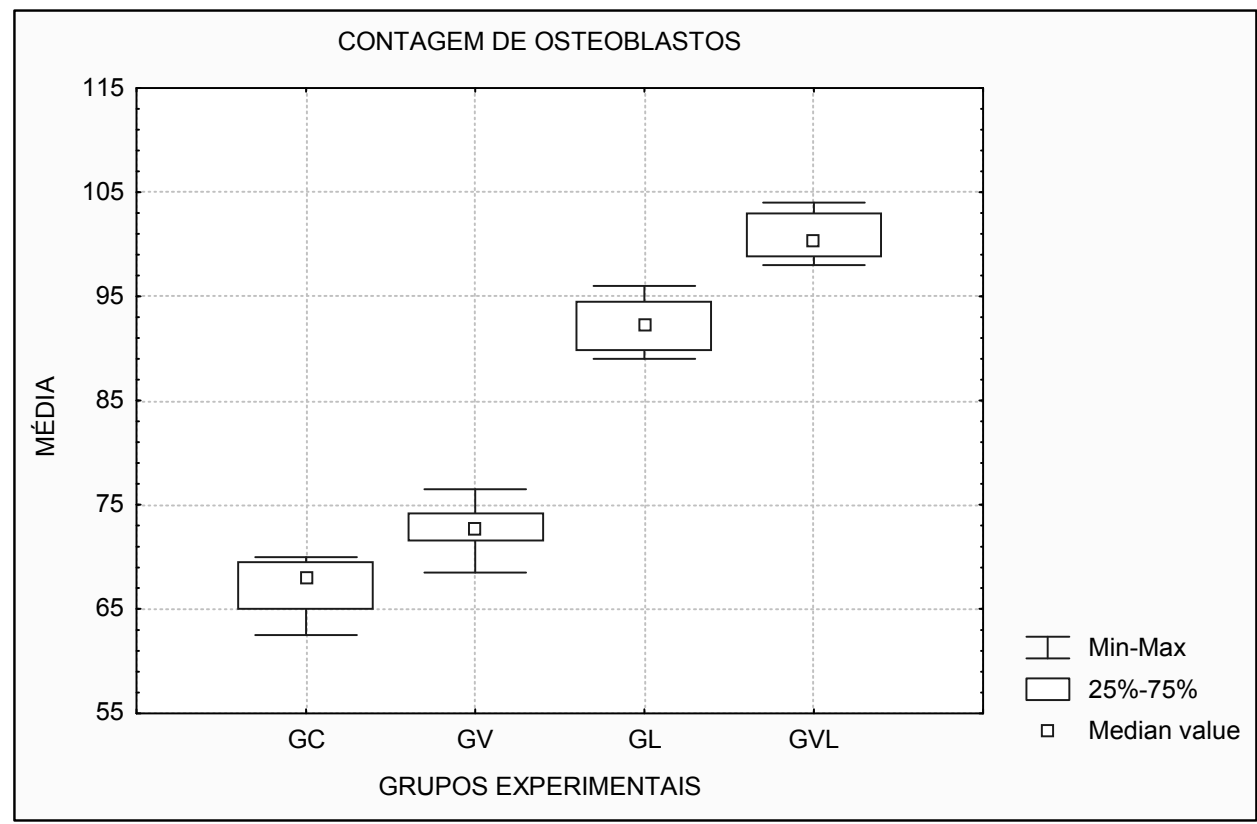

Figura 18 Diferença entre as medias de osteoblastos nos grupos, o GC apresenta a menor contagem de osteoblastos, o GV apresenta um sensível aumento em relação ao GC sugerindo um estimulo positivo na atividade osteoblástica pelo vitrocerâmico, o GL apresenta um aumento consistente sugerindo uma estimulação pela radiação laser, e finalmente o GVL apresentou a maior media, possivelmente pela soma dos estímulos. 
Abaixo estão os padrões dos exemplares com 13 dias, é possível notar maior quantidade de tecido lamelar (secundário) em todos os grupos em comparação com os indivíduos aos sete dias. Os grupos que receberam a TLBI encontram-se com maior quantidade de osso secundário em comparação com os não irradiados, sendo na presença do vitrocerâmico ou não.
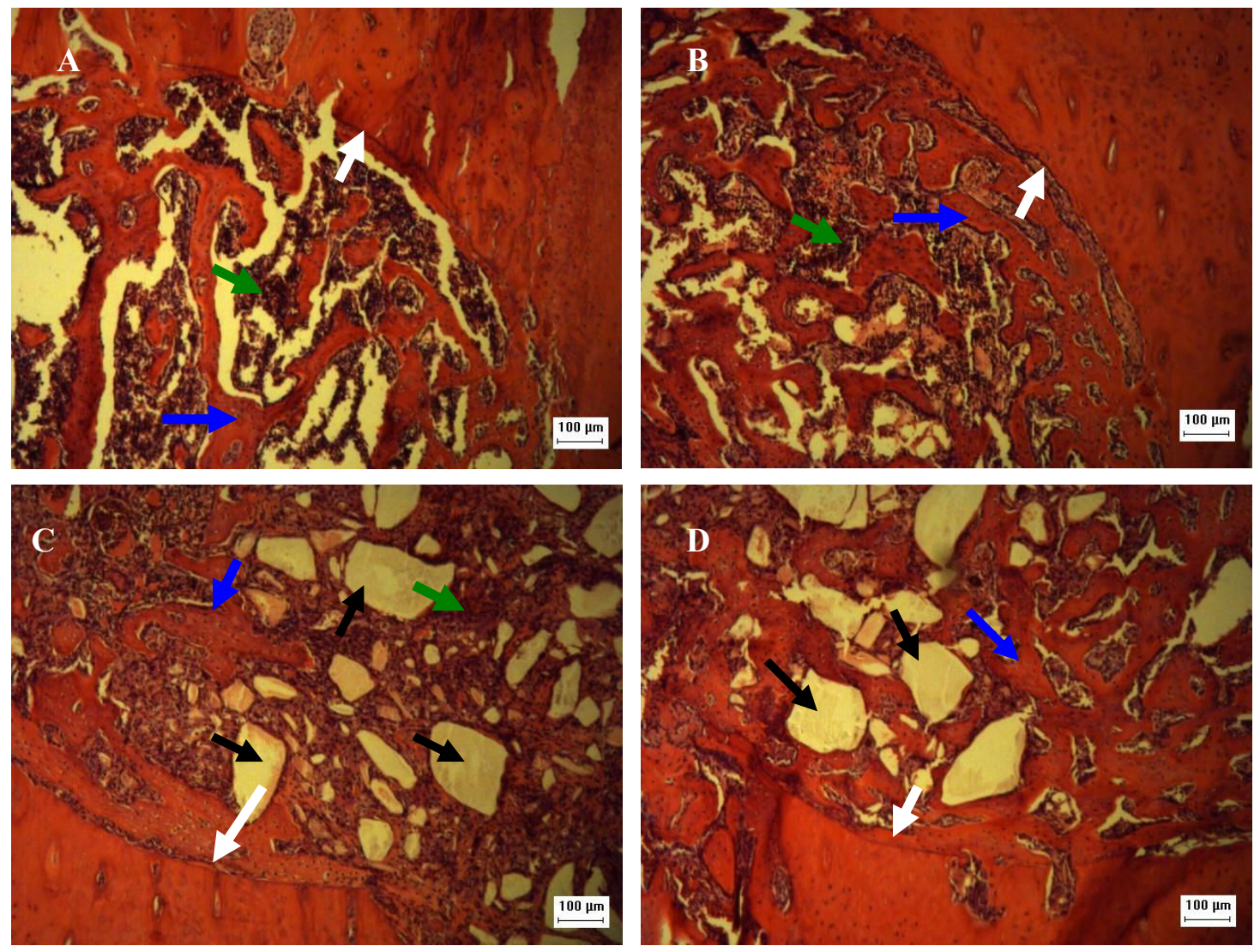

Figura 19: Lâminas dos animais sacrificados com 13 dias, coradas com H.E. (100X). A seta branca indica o limite da lesão; a azul, tecido secundário; a verde, tecido primário; e a preta, partículas de biomaterial. $\mathrm{O}$ grupo contole já apresenta abundante tecido ósseo secundário envolvendo tecido primário (A); o grupo irradiado apresenta uma maior quantidade de tecido secundário se comparado ao controle (B); o grupo com biomaterial apresenta a formação de tecido primário em torno do tecido osteóide que circunda o biomaterial $(\mathrm{C})$; o grupo com associação de biomaterial com LTBI apresenta o melhor grau de maturação do tecido com pequena quantidade de tecido secundário e poucas partículas de biomaterial (D). 

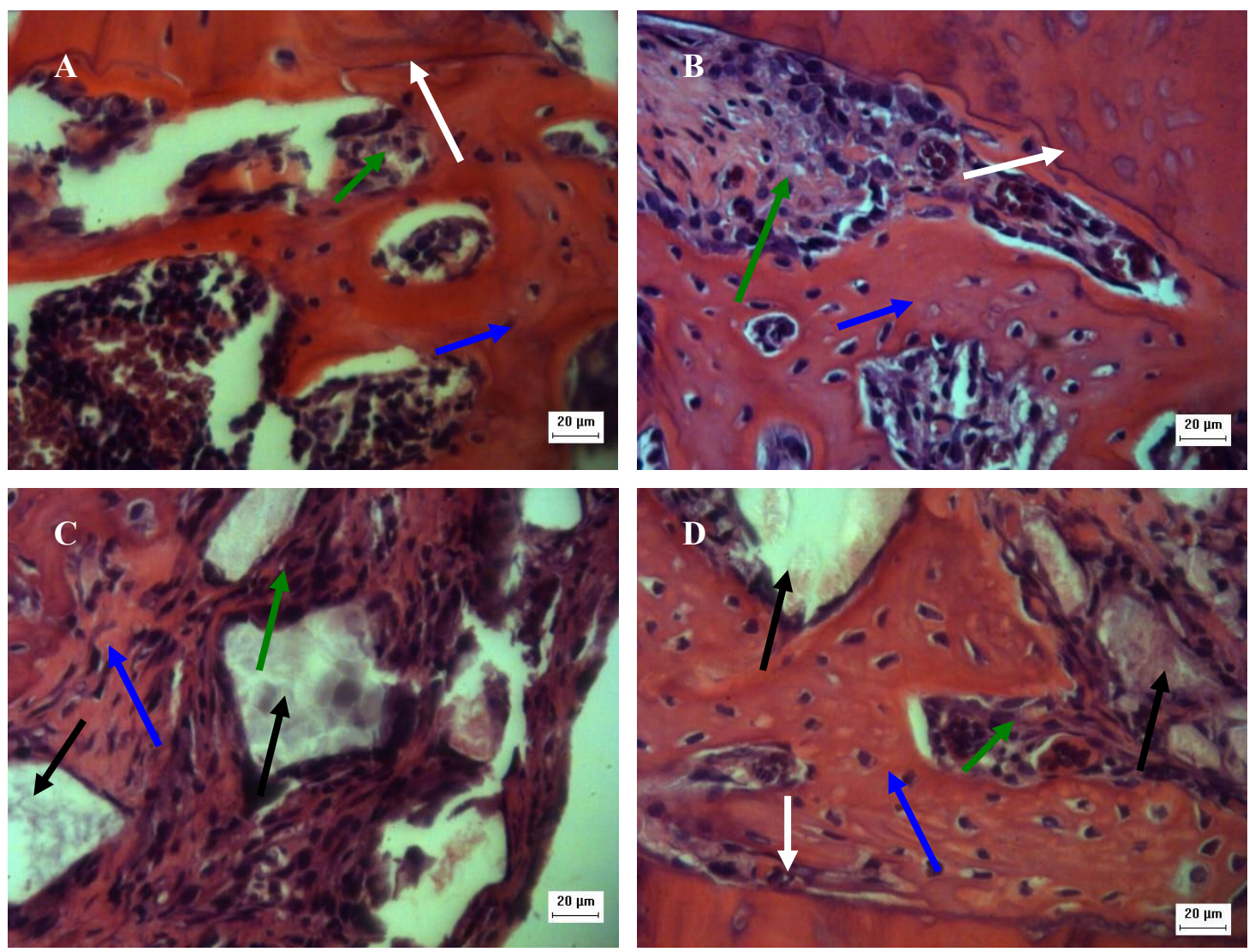

Figura 20. Lâminas coradas com H.E. dos animais sacrificados aos 13 dias (aumento original 500X). A seta preta indica partículas do biomaterial; a azul, tecido ósseo secundário; e a verde, tecido primário. $\mathrm{O}$ grupo controle apresenta formação óssea secundária ao redor do limite de lesão e parte do centro da mesma (A); o grupo irradiado apresenta-se no final do reparo, onde o tecido primário esta quase todo substituído por secundário (B); o grupo com biomaterial está com o tecido primário ao redor do biomaterial sendo substituído por tecido secundário $(\mathrm{C})$; e o grupo com biomaterial associado à TLBI está num estágio mais avançado em comparação ao que não foi irradiado (D).

Os dados quantitativos referentes à contaşem de osteoblastos aos 13 dias estão na tabela 7, e os valores de p para a diferença das médias entre os grupos estão na tabela 8 , onde os valores marcados em vermelho apresentam diferença estatisticamente significante $(\mathrm{p}<0,05)$. A figura 23 ilustra o gráfico da diferença entre as médias do número de osteoblastos entre os grupos aos 13 dias. 
Tabela 7. Médias do número de osteoblastos por grupo e seus respectivos desvios.

\begin{tabular}{l|r|c} 
& \multicolumn{1}{|c|}{ MÉDIA } & DESVIO PADRÃO \\
\hline GC & 50,25 & 1,732050808 \\
GV & 57,125 & 3,563204817 \\
GL & 73,625 & 3,36738559 \\
GVL & 69,5625 & 3,427176055
\end{tabular}

TABELA 8. Valores de p para diferença do número de osteoblastos entre os grupos.

\begin{tabular}{|c|c|c|c|c|}
\hline & GC & GV & GL & GVL \\
\hline & $M=50,250$ & $\mathrm{M}=\mathbf{5 7 , 1 2 5}$ & $M=73,625$ & $M=69,563$ \\
\hline GC & & 0,000873 & 0,000165 & 0,000165 \\
\hline GV & 0,000873 & & 0,000165 & 0,000165 \\
\hline GL & 0,000165 & 0,000165 & & 0,065082 \\
\hline GVL & 0,000165 & 0,000165 & 0,065082 & \\
\hline
\end{tabular}




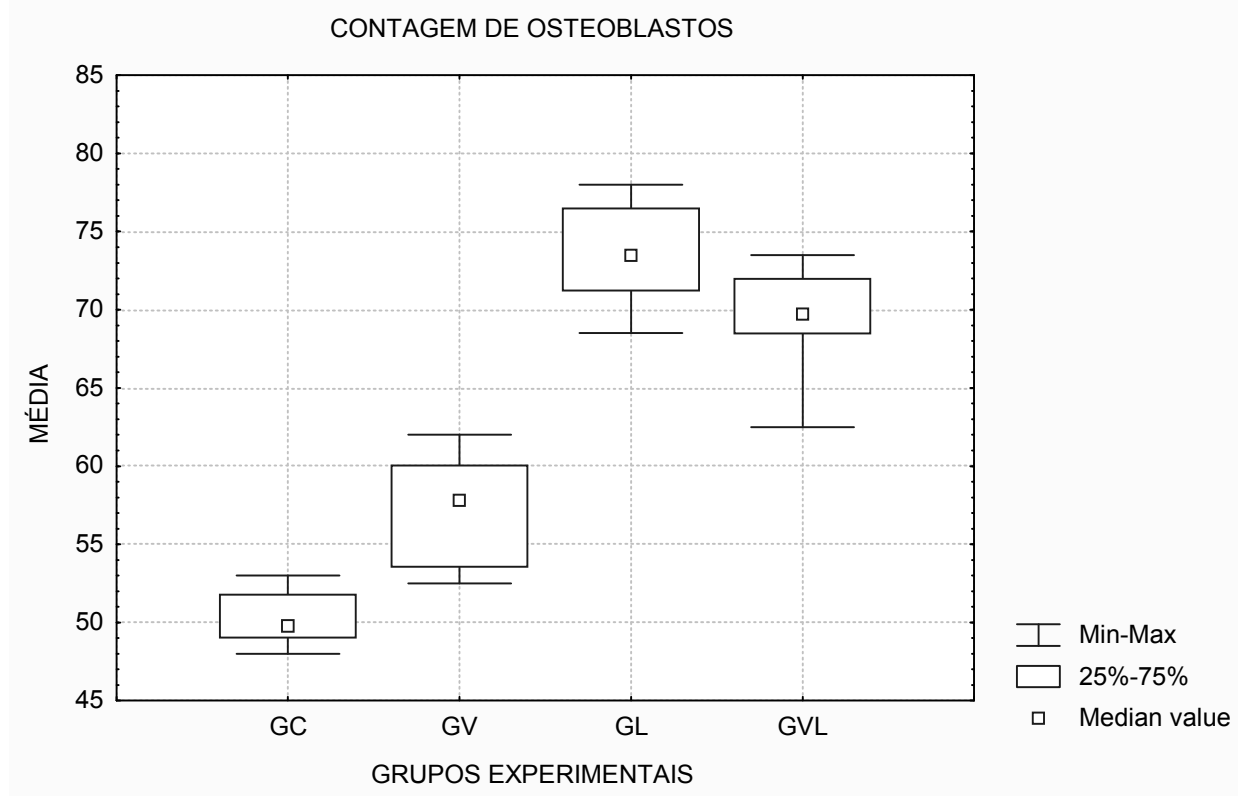

Figura 21. Diferença entre as médias de número de osteoblastos entre os grupos. O grupo GV apresenta um numero superior de osteoblastos se comparado com o controle (GC), porem menor se comparado ao GL e GVL. Sendo que GL e GVL não apresentam diferença estatística entre si.

\subsection{Análise de microscopia eletrônica de varredura}

Abaixo estão os exemplares com vitrocerâmica nos dois períodos avaliados, com e sem a influência da TLBI. É possível notar a maior neoformação óssea nos grupos irradiados nos dois períodos em comparação com os que não receberam o tratamento com o laser, e fica evidente que as partículas de vitrocerâmica estão sendo substituídas por osso neoformado à medida que vão sendo reabsorvidas. 

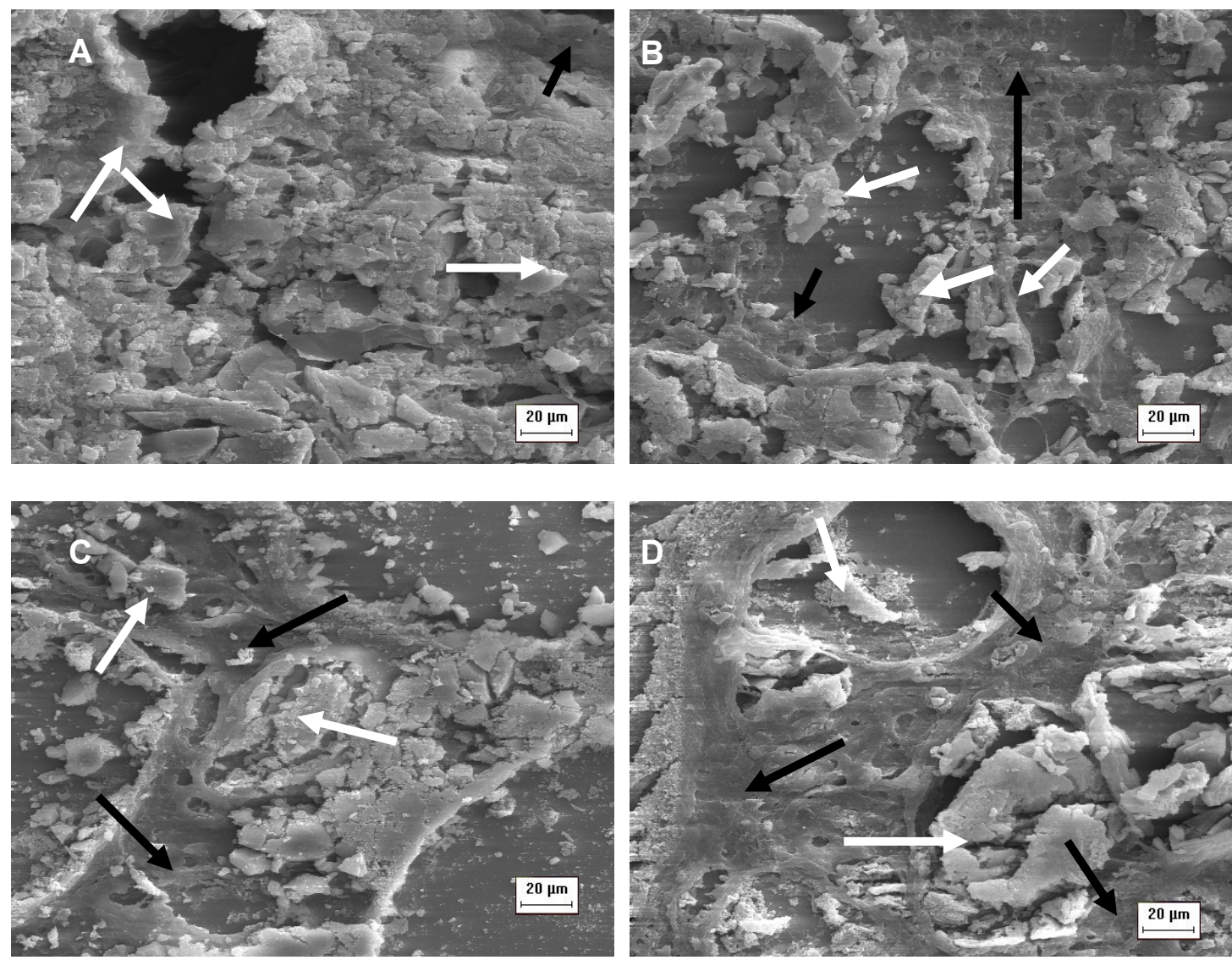

Figura 22: Microscopia eletrônica de varredura com aumento original de 500X (as setas pretas indicam tecido ósseo e as setas brancas indicam partículas do biomaterial). O grupo no qual foi aplicada a vitrocerâmica apresenta início de pequena neoformação óssea no sétimo dia (A); o grupo em que foi aplicado a vitrocerâmica associada à TLBI pode-se observar um incremento na formação óssea com relação ao não submetido à irradiação, aos 7 dias (B); no $13^{\circ}$ dia observa-se uma quantidade maior de tecido ósseo e há indícios de absorção do biomaterial (C); com a combinação da aplicação do biomaterial com a TLBI nota-se que a formação óssea foi superior que na ausência do estímulo da radiação laser. 


\section{DISCUSSÃO}

\subsection{Análise de microscopia de luz polarizada}

A avaliação das lâminas coradas com Picro Sirius tem como objetivo quantificar a organização da matriz extracelular, e verificar qualitativamente a disposição da deposição de tecido anisotrópico no foco de lesão.

$\mathrm{Na}$ avaliação qualitativa do brilho de birrefringência, nota-se que no período de sete dias o tecido anisotrópico está presente em menor quantidade nos grupos com vitrocerâmico, se comparados com os grupos controle e GL, e que a radiação laser fornece um estímulo positivo na organização da matriz extracelular, tanto na presença como na ausência do vitrocerâmico.

Os resultados quantitativos obtidos nos grupos com sete dias demonstram um retardo inicial na organização do tecido formado nos grupos GV e GVL em relação ao controle, possivelmente pelo fato das partículas do vitrocerâmico não terem sido reabsorvidas numa taxa que permitisse uma formação de lamelas mais espessas e anisotrópicas. Porém, a radiação laser induziu uma maior organização tecidual no mesmo período, no grupo GVL induziu a uma melhora estatisticamente significante em relação ao grupo que tinha recebido apenas o implante. E o grupo com melhor organização tecidual no período de sete dias foi o GL, onde o tecido anisotrópico esta presente com fibras delgadas e difusas, sugerindo uma fotobiomodulação do reparo ósseo logo nos estágios iniciais. Todos os grupos apresentaram diferenças estatisticamente significantes entre si $(p<0,05)$.

$\mathrm{Na}$ avaliação qualitativa no período de 13 dias observa-se a formação de tecido anisotrópico em todos os grupos. O controle apresenta lamelas organizadas e espessas na 
região periférica da lesão, o grupo GV apresenta lamelas menos espessas, porém as mesmas estão dispostas de forma mais uniforme e difusa incluindo as regiões mais centrais da lesão. $\mathrm{O}$ Grupo GL apresenta alto grau de anisotropia com tecido espesso em quase toda extensão do defeito ósseo e o GVL apresenta tecido anisotrópico cobrindo toda a área da lesão, excetuando-se a área ocupada pelas partículas do vitrocerâmico, as quais ficaram circundadas de tecido anisotrópico espesso e com alto brilho.

$\mathrm{Na}$ avaliação quantitativa do período de 13 dias, os resultados demonstraram que houve um aumento na maturação do tecido em todos os grupos em relação aos de sete dias, porém, o grupo GV apresentou menor brilho de birrefringência que o controle $(p<0,05)$, o motivo parece ser que o tempo para a ocorrência da reabsorção das partículas de vitrocerâmico não tenha ocorrido numa taxa suficiente para permitir maior maturação tecidual. O grupo GVL apresentou média muito superior ao controle $(\mathrm{p}<0,05)$, sugerindo uma melhora na interação tecido-implante, e o grupo GL apresentou a maior média, diferenciandose do controle $(p<0,01)$ e quando comparado ao GVL, não apresentou diferença estatisticamente significante $(\mathrm{p}>0,05)$.

Este retardo inicial (até 30 dias) em se tratando de biomateriais é corroborado por Becker et al (1994). Contudo, Guastaldi (2004) afirma que o atraso inicial do processo de reparo pode ser entendido como uma reação fisiológica natural, porque na presença de partículas de enxerto a deposição óssea ao redor do material é mais lenta e diretamente proporcional à absorção do mesmo, promovendo uma equivalência reparativa somente nos períodos cronológicos finais de 30 a 60 dias; podendo até mesmo alcançar ganho ósseo que nos defeitos controle, citado por alguns autores como Pinto (2003), Artzi (2000), Limeira Júnior (2004).

Pretel (2005) em um estudo com poliuretana de mamona associada à BMP e à laserterapia, encontrou menor anisotropia no grupo com o biomaterial apenas, já os grupos 
com laser e biomateriais associados ao laser apresentaram maior anisotropia que o controle, e os mesmos não eram estatisticamente diferentes entre si, corroborando com os resultados obtidos neste estudo, apesar de se tratar de um material de outra natureza.

No presente estudo o nível de significância adotado foi $\mathrm{p}<0,05$, se o teste estatístico tiver sua potência aumentada e for considerado $p<0,01$ como estatisticamente significante. $O$ grupo GV com 13 dias teria um grau de anisotropia considerado semelhante ao controle, em contrapartida, os demais grupos permaneceriam estatisticamente diferentes entre si, o que demonstra que o nível de anisotropia tecidual na presença do vitrocerâmico utilizado, chega próximo ao nível alcançado pelo controle muito mais precocemente que o citado por Guastaldi (2004).

\subsection{Análise de microscopia de luz comum}

As fotomicrografias coradas com Hematoxilina e Eosina foram utilizadas para contagem de osteoblastos e na observação de sua interação com o vitrocerâmico aplicado e também na avaliação qualitativa da matriz extracelular depositada.

Qualitativamente aos sete dias, é notável a intensa presença de células em todos os grupos com formação de tecido primário. O grupo GL apresenta início de formação de tecido secundário, sugerindo uma influência da radiação laser logo nos estágios iniciais do reparo. $\mathrm{O}$ GV apresenta tecido primário ao redor das partículas do vitrocerâmico com osteoblastos dispostos lado a lado, circulando o biomaterial, esta disposição é característica de osteoblastos engajados na deposição de matriz extracelular. E o GVL, apresentou início de formação de 
tecido secundário com deposição de matriz mais organizada e íntima relação dos osteoblastos com o vitrocerâmico.

$\mathrm{Na}$ contagem de osteoblastos aos sete dias, foi notado um aumento do número no grupo GV em comparação ao controle, o que sugere uma estimulação da atividade osteoblástica por parte do vitrocerâmico. O grupo GL, apresentou uma média superior ao controle, sugerindo que houve uma foto-bioestimulação da atividade osteoblástica. O grupo com maior número de osteoblastos foi o GVL, possivelmente pela soma da estimulação dada pelo vitrocerâmico e pela TLBI.

Qualitativamente aos 13 dias, nota-se a deposição de tecido secundário em todos os grupos, porém, no controle existem grandes espaços na região central da lesão com tecido osteóide em deposição; o GV apresenta tecido secundário em torno do tecido osteóide em organização, que envolve partículas de vitrocerâmico; e o GVL, apresenta grande quantidade de tecido secundário e tecido osteóide incorporando algumas partículas de vitrocerâmico.

$\mathrm{Na}$ análise feita aos 13 dias, o número de osteoblastos já era inferior do que em sete dias, isto provavelmente porque muitos já estavam envoltos por matriz organizada e tornaramse osteócitos. O grupo GV apresentou um número superior de osteoblastos em relação ao controle, sugerindo uma atividade superior ainda neste período; o GL também apresentou um número superior ao controle, sugerindo que a radiação laser ainda esta estimulando a atividade de neoformação óssea; o GVL apresentou um número superior ao controle e ao GV, porém não foi estatisticamente significante em relação ao GL.

Com base nestes resultados, é possível afirmar que o vitrocerâmico utilizado estimulou a atividade dos osteoblastos, bem como a LTBI exerceu uma forte influência sobre os osteoblastos.

A estimulação de osteoblastos pelos vidros bioativos com $45 \%$ de $\mathrm{SiO}_{2}$ é comumente citada na literatura. Estudos in vitro, mostram que os vidros bioativos estimulam o 
crescimento e maturação dos osteoblastos, promovendo a expressão e manutenção do fenótipo dos mesmos (XYNOS et al 2000; LOTY et al 2001; BOSETTI e KANNAS 2005).

Nicolau et al. (2003), avaliaram a ação do laser de baixa potência GaAlAs, comprimento de onda de $660 \mathrm{~nm}$, em defeitos ósseos criados em fêmures de ratos. O laser foi aplicado em dias alternados até o $8^{\circ}$ dia do pós-operatório. Após avaliação histomorfométrica, os autores observaram que o laser de baixa potência aumentou tanto a atividade dos osteoclastos como a dos osteoblastos, levando a concluir que o LTBI pode acelerar a fase inicial do reparo ósseo.

Guzzardella et al. (2002), avaliaram a influência do laser de baixa potência em osteoblastos de fêmures de ratos que foram mantidos em meio de cultura por 21 dias. O laser de GaAlAs, no comprimento de onda de $780 \mathrm{~nm}$, foi utilizado na potência de $1 \mathrm{~W}$, média de repetição por pulso de $300 \mathrm{~Hz}$, dosimetria de $300 \mathrm{~J} / \mathrm{cm} 2$. As aplicações foram feitas diariamente por 10 dias. Os resultados deste estudo in vitro indicaram que após 21 dias houve um significativo aumento do metabolismo celular, quando comparado com o grupo controle, sugerindo que o laser de baixa potência produziu um efeito positivo na estimulação do tecido ósseo

Takeda (1988) utilizou o laser de baixa potência GaAlAs no infravermelho, em animais com periodontite. Foi realizada apenas uma aplicação $(25 \mathrm{~mW} / \mathrm{cm} 2$ e $20 \mathrm{~J} / \mathrm{cm} 2)$. Os resultados mostraram uma proliferação acentuada de osteoblastos e uma deposição maior de tecido osteóide nos animais que receberam a laserterapia.

Lirani et al., executaram um estudo em que após a confecção de um defeito na tíbia de ratos, tratou-os com LTBI no $\lambda 780 \mathrm{~nm}$ potência de $30 \mathrm{~mW}$ e dose de $112,5 \mathrm{~J} / \mathrm{cm}^{2}$. O grupo irradiado apresentou um aumento significativo no número de osteoblastos e na quantidade de tecido ósseo neoformado. 
Pinheiro et al., (2003) realizaram um estudo para avaliar o efeito do laser de baixa potência GaAlAs $(830 \mathrm{~nm}, 40 \mathrm{~mW})$, no processo de reparo ósseo em defeitos criados em fêmures de ratos. As cavidades ósseas foram enxertadas com osso inorgânico bovino e recobertas com membrana de osso cortical bovino descalcificado. Os defeitos receberam uma dose de energia total de $112 \mathrm{~J} / \mathrm{cm} 2$. Os resultados avaliados após 15, 21 e 30 dias, mostraram que a LTBI exerceu um efeito positivo na biomodulação do reparo ósseo nesses defeitos, independente do uso ou não da membrana óssea bovina.

\subsection{Análise de Microscopia Eletrônica de Varredura}

O cuidado no preparo de amostras a serem avaliadas por MEV é importante considerando que de um lado há um instrumento que irradia um feixe de elétrons e de outro um tecido biológico. As amostras biológicas são comumente moles, úmidas, tridimensionais, apresentam baixa condutividade elétrica e são muito sensíveis à radiação, GOLDSTEIN et al (1994).

Este conjunto de características faz com que haja necessidade de transformar uma amostra úmida em amostra seca que preserve sua tridimensionalidade e composição química, permitindo examiná-la e avaliá-la no vácuo do microscópio, esta conversão pode ser separada em três fases distintas: fixação, desidratação e cobertura (metalização) GOLDSTEIN et al (1994).

Os resultados obtidos com esta análise no presente estudo, demonstram tendência a uma maior neoformação óssea sob a influência da radiação laser nos dois períodos avaliados (7 e 13 dias). 
Ficando também evidente que, com o passar do tempo, as partículas do biomaterial estão sendo substituídas por tecido ósseo neoformado à medida que são reabsorvidas.

Estes resultados indicam a seguinte tendência: esta diminuição estaria relacionada com a "cobertura" do vitrocerâmico pelo novo osso em crescimento. O que reforça a hipótese de potencial osteocondutor do biomaterial. (GLOWACKI e SPECTOR 1990)

\subsubsection{Considerações finais}

Com base nos resultados obtidos através das avaliações qualitativa e quantitativa, do brilho de birrefringência, contagem de osteoblastos e análise de superfície fica clara a influência da LTBI sobre o reparo ósseo na presença ou não do vitrocerâmico de composição em porcentagem de peso: $45 \% \mathrm{SiO}_{2}, 24,5 \% \mathrm{Na}_{2} \mathrm{O}, 24,5 \% \mathrm{CaO}$ e $6 \% \mathrm{P}_{2} \mathrm{O}_{5}$.

O vitrocerâmico empregado apresentou potencial osteocondutor estimulando os osteoblastos e favorecendo a deposição de tecido nas regiões mais centrais da lesão com aumento na formação de tecido ósseo no período de 13 dias, apesar da anisotropia um pouco inferior neste período inicial, explicada pelo fato do curto período disponível para a reabsorção das partículas, e corroborado por vários estudos. (BECKER et al., 1994), GUASTALDI (2004) PINTO (2003), ARTZI (2000), LIMEIRA JÚNIOR (2004). 


\section{CONCLUSÕES}

- A partir dos resultados parciais apresentados, é possível concluir que a vitrocerâmica de composição em porcentagem de peso $45 \% \mathrm{SiO}_{2}, 24,5 \% \mathrm{Na}_{2} \mathrm{O}, 24,5 \% \mathrm{CaO}$ e $6 \% \mathrm{P}_{2} \mathrm{O}_{5}$, após ser recozido em cuba de inox acima de sua temperatura de transição vítrea, a $620^{\circ} \mathrm{C}$ por 30 minutos e mantido a $790^{\circ} \mathrm{C}$ por 60 minutos, apresenta características de material de preenchimento e potencial osteocondutor.

- A laserterapia de baixa intensidade mostrou-se um eficiente meio bioestimulante no comprimento de onda $780 \mathrm{~nm}$, com potência de $30 \mathrm{~mW}$, dose de $112,5 \mathrm{~J} / \mathrm{cm}^{2}$ e energia total de $4,5 \mathrm{~J}$.

- Quando o tecido é irradiado com laser na presença do biomaterial em estudo, a interação é otimizada melhorando a qualidade do tecido ósseo neoformado e sua interação com o material. 


\section{REFERÊNCIAS BIBLIOGRÁFICAS}

ALMEIDA-LOPES, L.; VÉLEZ-GONZÁLEZ, M.; BRUGNERA, A. Jr.; PINHEIRO, A. B. The use low level laser therapy for wound healing: Clinical study. In: ANNUAL MEETING- lasers in surgery and medicine, Proceedings... Florida, EUA p.16-18. 1999.

ALMEIDA-LOPES, L. et al. Comparison of the low level laser therapy effects on cultured human gingival fibroblasts proliferation using different irradiance and same fluence lasers in surgery and medicine. New York, v.29, n.2, p.179-184. 2001

ALMEIDA-LOPES, L. Aplicações clínicas do laser não-cirúrgico. In: BRUGNERA, A. Jr.; PINHEIRO, A. L. B. Laseres na odontologia moderna. São Paulo: Pancast, p.99-120. 1998.

ALMEIDA-LOPES, L. Laser. J Bras Odontol Clin, v.1, n.4, p.3-5, jul/ago. 1997.

ARRUDA, ERB et al. Influência de diferentes comprimentos de onda da laserterapia de baixa intensidade na regeneração tendínea do rato após tenotomia. Rev. bras. fisioter., São Carlos, v. 11, n. 4, 2007

ARTZI Z, TAL H, DAYAN D. Porous bovine bone mineral in healing of human extraction sockets. Part 1; Histomophometric evaluation at 9 months. J Periodontol; 71(6):1015-25. 2000 
BARUSKA, O.; YAAKOBI, T.; ORON, U. Effects of low- energy laser (He-Ne) irradiation on the process of bone repair in the rat tibia. Bone, v.16, n.1, p. 47-55, 1995.

BAXTER GD; Therapeutic Lasers- Theory and Practice. London: Editora Churchill Livingstone, 1994.

BECKER W, BECKER B.E., CAFFESSE R. A comparison of desmineralized freeze-dried bone and autologous bone to induce bone formation in human extraction sockets. $\mathbf{J}$ Periodontol; 65(2):1128-33, 1994.

BOSCHI, A.O., O que é necessário para que um material seja considerado biomaterial? In: Seminário Regional de Biomateriais, Santa Catarina (1996) Anais. Santa Catarina, UDESC. p.4-16 1996.

BOURGELAISE, D. B. C. The physics of lasers. In: ARNDT, K. A. Cuttaneous laser therapy. New York: John Wiley \& Sons,. p.13. 1983.

BUSER, D. et. al. Regeneração óssea guiada na implantodontia $1^{\mathrm{a} e d}$. Livraria Santos Editora, São Paulo, 249p., 1996.

CALDERHEAD, R. G. The Nd:YAG and GaAIAs lasers: a laser comparative analysis in pain therapy. In: ATSUMI, K.; NIMSAKUL, N. Laser. Tokyo: Japan Society for Laser Medicine, v.21, n.1, 1981. 
CANCIAN, D, C. HOCHULI-VIEIRA, E. MARCANTONIO, R. A. MARCANTONIO, E jr use of biogran in bone defects: histologic study in monkeys (Cebus apella). The international journal of oral \& maxillofacial implants. V.14, ed.6, p: 859-64 1999.

CONSENSUS CONFERENCE OF THE EUROPEAN SOCIETY FOR BIOMATERIALS, Chester, 1986; Proceedings. Amsterdam, D F WILLIANS. Elsevier, 1987.

COTRAN, R.S., KUMAR, V., ROBINS, S.L. Robins, patologia estrutural e functional $5^{\text {a }}$ edição Rio de Janeiro Guanabara Koogan 1994.

DAMANTE, C. A., Avaliação clínica e histológica dos efeitos do laser em baixa intensidade (GaAlAs) na cicatrização de gengivoplastia em humanos. Dissertação de Mestrado da Universidade de São Paulo, 2003.

DA SILVA, R.V., CAMILI, J.A. Repair of bone defects treated with bone graft and low power laser. The jornal of craniofacial surgery. V17 ed.2 p: 297-301 mar, 2006.

DYSON, M. Mechanisms involved in therapeutic ultrasound. Physiotherapy, v.73, n.3, p.116-120, 1987.

FREITAS, I.G.F.; BARANAUSKAS, V.; CRUZ-HOFLING, M.A. Laser effects on osteogenesis. Aplied Surface Science, v.154-155 p.548-554, feb. 2000.

FULLER, A. T. Fundamentals of lasers in surgery and medicine. In: DIXON, J. A. (Ed). Surgical applications of lasers. Chicago: Year Book Medical Publishers, p.11. 1983. 
GARAVELLO, I., BARANAUSKAS, V., DA CRUZ-HOFLING, M. A. The effects of low laser irradiation on angiogenesis in injuried rat tibiae. Histology and histopatology. V. 19 ed. 1 p: 43-8 Jan. 2004.

GARTNER, L.P.; HIATT, J.L. Tratado de Histologia 2a ed., Rio de Janeiro: Guanabara Koogan, 456p.2003.

GJELSVIK, A. Bone remodeling and piezoelectricity J Biomech., New York, v.6 n.1, p. 69-77, jan. 1973.

GLOWACKI, J.; SPECTOR, M. Tissue responses to bone-derived and synthetic materials In: DAVIES, J. E. (1990) The bone-biomaterial interface United States, University of Toronto Press, 1990.

GOLDMAN, L. The biomedical laser: technology \& clinical applications. New York: Springer Verlag, p.5-25. 1981.

GOLDSTEIN, J. I.; NEWBURY, D. E.; ECHILIN, P.; JOY, D.C.; ROMIG A.D. jr.; LYMAN, C.E.; FIORI, C.; LIFSHIN E. Scanning electron microscopy and X-ray microanalisis - A text for biologists, material scientists, and geologists, Cap. 12-132 ed. United States of America Plenum Press, 1994.

GUASTALDI, A.C. Biomaterial - ponderações sobre as publicações científicas. Rev. assoc. paul. Cir. Dent., São Paulo, v.58, n.3, p.205-206, 2004. 
GUZZARDELLA, G.A. et al Laser technology in orthopedics: preliminary study on low power laser therapy to improve the bone material interface. Int. J. Artif. Organs. V.24 n.12 p.898-902 dec. 2001.

GUZZARDELLA, G.A. et al. Laser stimulation on bone defect healing: an in vitro study. Lasers Med Sci, v. 17, p. 216-220, 2002.

HALL, B.K. Bone vol. 1: the osteoblast and osteocyte. The Telford Press.

HARRIS, D.M., Biomolecular Mechanisms of laser biostimulation. J. clin. Laser Med. Surg., v.9, n.4, p.277-79, Aug. 1991.

HECKMAN, J. D. et al . Acceleration of tibial fracture-healling by non invasive, lowintensity pulsed ultrasound. The journal of bone and joint surgery, v.76-A, n.1, jan. 1994.

HENCH, L.L., Bioceramics. Journal of American Ceramic Society, v.81,n.7,p.1705-28. 1998.

JACQUES, S. L. Absorption coefficient to different wavelength. Tabela interna de consulta do Laser Biology Research Laboratory of Univ. of Texas M. D. Anderson Cancer Center. Houston, Estados Unidos, 1995.

JÓZSA, L., KANNUS, P. Human Tendon, United States of America: Human Knectics, 1997. 
JUNQUEIRA, L.C., e CARNEIRO, J. Histologia básica 7 ed. Rio de Janeiro, Guanabara, 1990.

JUNQUEIRA, L.C.U.; BIGNOLAS, G.; BRENTANI, R.R. A simple and sensitive method for the quantitative estimation of collagen. Anal. Biochem. , v.94, n.1, p.96-99, 1979.

KATCHBURIAN, E.; ARANA, V. Histologia e embriologia oral: Texto-atlas correlações clínicas, $1^{\text {a }}$ ed. São Paulo Panamericana 381 p., 1999.

KARU, T. et al.( Irradiation with He-Ne laser increases ATP level in cells cultivated in vitro Journal of Photochemistry and Photobiology B., Lausanne, v. 27, n. 3, p.219-223, 1995.

KARU, T. I. Biological action of low intensity visible monochromatic light and some of as medical applications. In: GALLETI, G. (Ed). Laser. Bologna, Itália.. p.381. 1985.

KARU, T. I. Photobiological fundamentals of low power laser therapy. IEEE Journal Quantum Electronics QE-23, v.10, p.1703-1717, 1987.

KHADRA, M., RONOLD, H. J, LYNGSTRADAAS, S. P., ELlingSEN, J. E., HAANAES, H. R.Enhancement of bone formation in rat calvarial bone defects using lowlevel laser therapy. oral surgery, oral medicine, oral pathology, oral radiology, and endontics. v.97 ed.6 p 693-700 jun, 2004. 
KHADRA, M., RONOLD, H. J, LYNGSTRADAAS, S. P., ELLINGSEN, J. E., HAANAES, H. R. Low-level laser therapy stimulates bone-implant interaction: an study in rabbits. clinical oral implants research, v.15 ed.3 p 325-32 jun, 2004.

KITCHEN, S. S; PARTRIDGE, C. J.. A review of low level laser therapy. Physioterapy, v.77, n.3, p. 161-168. mar, 1991.

LIRANI-GALVÃO, A.P.R.; JORGETTI, V.; SILVA, O. L. Comparative study of how lowlevel laser therapy and low-intensity pulsed ultrasound affect bone repair in rats. Photomedicine \& Laser Surgery, v. 24, p. 735-740, 2006.

LIMEIRA JÚNIOR FA. Estudo do reparo de defeitos ósseos irradiados com laser 830nm submetidos ou não a implante de hidroxiapatita sintética e/ou membrana de osso bovino. [Tese]. Salvador: Universidade Federal da Bahia, 2004.

LUGER, E.J. et al Effect of low power laser irradiation on the mechanical proprieties of bone fracture healing in rats. Lasers Surgery and Medicine, v.22, n.2 p.97-102, 1998.

MAIMAN, T.H. Stimulated optical radiation in ruby. Nature, v.187, p.493, 1960.

MAYR, E. et al. Does low intensity, pulsed ultrasound speed healling of scaphoid fractures? Handchir Mikrochir Plast Chir. V.32, n.2, p.115-22. Mar. 2000. 
MARINO, J.A.M. Efeito do laser terapêutico de baixa potência sobre o processo de reparação óssea em tíbia de rato. 107 p. Dissertação (mestrado) - Universidade Federal de São Carlos. São Carlos, 2003.

MESTER, E., MESTER, A.F., MESTER, A The biomedical effects of laser aplication, Lasers in Surgery and medicine. v. 5, p. 31-39. 1985.

MESTER, E. A laser sugar alkamazaea a gyogyaezatban. Orv Hetilap, v.107, p.1012, 1966.

MORRONE, G.; GUZZARDELlA, G. A.; ORIENTI, L.; GIAVARESI, G.; FINI, M.; ROCCA, M.; TORRICELLI, P.; MARTINI, L. GIARDINO, R. Muscular trauma treated with a Ga-Al-As diode laser: In Vivo experimental study. Lasers Med Sci, v.13, p.293-298, 1998.

MOURA, J. TEIXEIRA,L.N. RVAGNANI,C. PEITL,O. ZANOTTO,E.D. BELOTI, M.M. ROSA, A.L. OLIVEIRA,P.T. In vitro osteogenesis on a higly bioactive glass-ceramic. Willey Intercience 2006.

NICOLA, R. A., JORGETti, V., RIGAU, J., PACHEGCCO, M.T., DOS REIS, L.M. ZANGARO, R. A. . Effect of low-power GaSlAs laser $(660 \mathrm{~nm})$ on boné structure and cell activity: sperimental animal study Lasers in medical science V.18 ed. 2 p: 89-94. 2003. 
P. LI, Q. YANG, F. ZHANG and KOBUKO, the effect of residual glassy phase in a bioactive glass-cerâmic on the formation of its surface apatite layer in vitro, J. Mater. Sci. Mater. Med., 3(6), 452-456, 1992.

PINHEIRO, A. L., GERBI, M. E. Photoengineering of bone repair. Photomedicine and laser surgery. V.24 ed.2 p: 169-78, 2006.

PINTO L.P.; Brito J.H.M.; Oliveira M.G. Avaliação histológica do processo de reparo ósseo na presença da proteína morfogenética óssea (Gen-Proß) associada com membrana biológica (Gen-Derm®). Rev Bras Cir Protese Implant; 10(37):25-32, 2003.

PÖNTINEN, P. J. Low level laser therapy as a Medical treatment modality. Tampere: Art Urpo, p. 13-17. 1992.

PRETEL H, LIZARELLI RF, RAMALHO, LT. Effect of low-level laser therapy on bone repair: histological study in rats. Lasers Surg Méd. V. 39 Ed: 10 p. 788-96, 2007.

RAY, R. D.; HOLLOWAY, J.A. Bone implants preliminary an experimental study J BoneJoint Surg. Am. Boston V. 39-A, n.5 p.1119-1128 OCT, 1957.

REYES, L. C. V. Aplicação de um vidro bioativo em tíbias de coelho.. 70f. Dissertação (mestrado) UNIVERSIDADE DE SÃO PAULO- SÃO CARLOS- SP, 2000.

ROLLO, J. M. D. de A. Estudo sobre o revestimento cerâmico em próteses metálicas. São Carlos. 67p Dissertação (Mestrado) - Escola de Engenharia de São Carlos, 1978. 
ROSS, M.H.; REITH, E.J.; ROMRELL, L.J. Histologia, texto e atlas, $2^{a}$ edição São Paulo Editorial médica Paramericana, 1993.

TAKEDA, Y. Irradiation effect of low energy laser on alveolar bone after tooth extraction. Int J Oral Maxillofac Surg, v. 17, n. 6, p. 388-391, 1988.

TEN CATE. Histologia bucal desenvolvimento, estrutura e função $5^{\text {a }}$ edição Rio de Janeiro: Guanabara Koogan 439p., 2001.

TIPHLOVA, O., KARU, T. Stimulation of Escherichia coli division by low-intensity monochromatic visible light. Photochemistry and photobiology 48(4) p.467-71, oct. 1988.

TRELLES, M.A.; MAYAYO, E. Bone fracture consolidates faster with low power laser. Lasers in Surgey and Medicine v.7, p.36-45, 1998.

VÄLIMÄKI, V.-V. ARO, H. T. Molecular Basis for action of bioactive glasses as bone graft substitute Scandinavian Journal of Surgery n.95, p. 95-102, 2006.

VEÇOSO, M. C. (1993) Laser em fisioterapia 1ª ed. São Paulo: ed. Louise Científica

VIDAL, B. C., Matrix extracelular. In: VIDAL, B.C., MELLO, M.L.S., Biologia Celular, Rio de Janeiro e São Paulo, Livraria Atheneu, pp.273-304, 1987 a. 
VIDAL, B. C., Métodos em Biologia Celular. In: : VIDAL, B.C., MELLO, M.L.S., Biologia Celular, Rio de Janeiro e São Paulo, Livraria Atheneu, pp.5-40, 1987b.

WILDEN, L.; KERTHEIN, R. Import of Radiation phenomena of electrons and therapeutic low-level laser in regard to the mitochondrial energy transfer. J. clin. Laser Med. Surg. v.16, n.3, 1998.

ZAVAGLIA, C. A. C., PURCHIO, R. A. J., BIERWAGEN, L. E., ZOLOTAR, M. S. O uso de novos materiais cerâmicos em próteses ortopédicas. In: I Seminário Regional de Biomateriais, Santa Catarina. Anais, p.18-31. Santa Catarina, UDESC 1996. 